NBER WORKING PAPER SERIES

\title{
SKIN OR SKIM? INSIDE INVESTMENT AND HEDGE FUND PERFORMANCE
}

\author{
Arpit Gupta \\ Kunal Sachdeva \\ Working Paper 26113 \\ http://www.nber.org/papers/w26113
NATIONAL BUREAU OF ECONOMIC RESEARCH
1050 Massachusetts Avenue
Cambridge, MA 02138
July 2019

We would like to thank Jules Van Binsbergen, Maria Chaderina, Quinn Curtis, Nickolay Gantchev, Qiping Huang, Clemens Sialm, Lin Sun, and Sumudu Watugala (discussants). We have also benefited from discussions with Simona Abis, Yakov Amihud, Charles Calomiris, Alan Crane, Kent Daniel, Colleen Honigsberg, Sabrina Howell, Wei Jiang, Ralph Koijen, Anthony Lynch, Stijn Van Nieuwerburgh, Tarun Ramadorai, Matthew Richardson, Paul Tetlock, James Weston, and Jeffrey Wurgler, as well as seminar participants at Berkeley (Haas), Columbia University (GSB), New York University (Stern), University of Pennsylvania (Wharton), Rice University (Jones), Yale University (SOM), NBER Long-Term Asset Management, the NASDAQ DRP Research Day, the 13th Annual Penn/NYU Conference on Law and Finance, IRMC, the CEPR ESSFM conference in Gerzensee, the Junior Entrepreneurial Finance and Innovation Workshop, the Hedge Fund Research Symposium, the 10th Hedge Fund and Private Equity Conference, the University of Kentucky Finance Conference, FIRS, MFA, NFA, SFS Cavalcade, Two Sigma, Q Group. We thank HFR, CISDM, eVestment, BarclayHedge, and Eurekahedge for data that contributed to this research. We gratefully acknowledge generous research support from the NYU Stern Center for Global Economy and Business and Columbia University. We thank Billy Xu for excellent research assistance. See https://www.skinorskim.org for Form ADV data used in this paper. The views expressed herein are those of the authors and do not necessarily reflect the views of the National Bureau of Economic Research.

NBER working papers are circulated for discussion and comment purposes. They have not been peer-reviewed or been subject to the review by the NBER Board of Directors that accompanies official NBER publications.

(C) 2019 by Arpit Gupta and Kunal Sachdeva. All rights reserved. Short sections of text, not to exceed two paragraphs, may be quoted without explicit permission provided that full credit, including (C) notice, is given to the source. 
Skin or Skim? Inside Investment and Hedge Fund Performance

Arpit Gupta and Kunal Sachdeva

NBER Working Paper No. 26113

July 2019

JEL No. G23,G32,J33,J54

\begin{abstract}
$\underline{\text { ABSTRACT }}$
Hedge fund managers contribute substantial personal capital, or "skin in the game," into their funds. While these allocations may better align incentives, managers may also strategically allocate their private capital in ways that negatively affect investors. We find that funds with more inside investment outperform other funds within the same family. However, this relationship is driven by managerial decisions to invest capital in their least-scalable strategies and restrict the entry of new outsider capital into these funds. Our results suggest that skin in the game may work as a rent-extraction mechanism at the expense of fund participation of outside investors.
\end{abstract}

Arpit Gupta

Stern School of Business

44 West 4th Street

New York, NY 10012

agupta3@stern.nyu.edu

Kunal Sachdeva

Rice University

Janice and Robert McNair Hall

Houston, TX 77005

kunal.sachdeva@rice.edu

A data appendix is available at http://www.nber.org/data-appendix/w26113

Source Data is available at www.skinorskim.org 
Of the $\$ 3$ trillion in assets under management by hedge funds, $\$ 400$ billion can be attributed to investments from insiders: general firm partners (GPs) and related parties. While this large allocation of insider capital can better align incentives between investors and hedge fund managers, regulators have also raised concerns that insider "skin in the game" may also have potentially adverse consequences. ${ }^{1}$ Because insiders have superior private information, have discretion over which of their funds to invest in, and may subsequently alter the fund operations; managers with large personal stakes may choose actions which negatively affect their investors.

Using a Berk and Green (2004)-style model, we show that the strategic allocation of private capital can help hedge fund managers raise earnings at the cost of capital participation by outside investors. Managers in our model face a tradeoff between the choice of earning returns on private capital against fee revenue levied on outside investors. This assumption is realistic, as we find empirically that returns on privately-invested capital are roughly as large for hedge fund managers as either management or performance fees (Figure I). When choosing where to allocate personal capital, managers internalize the fact that raising additional capital dilutes the fund's return due to decreasing returns to scale. Previous papers assessing decreasing returns to scale include: Yin (2016), Ramadorai (2013), Getmansky (2012), and Teo (2009). As a result, our model predicts that managers will invest their capital in their least-scalable strategies, and that they will operate these funds with greater insider capital at a smaller scale by restricting the entry of outside investors. In equilibrium, returns are higher for funds with more insider capital, but this increase comes at the cost of limited entry by outside investors.

In this paper, we examine three hypotheses: (I) hedge fund managers allocate their insider capital to their less-scalable strategies; (2) insiders will restrict access to outside investors in these funds; and (3) insider funds, as a consequence, outperform on a riskadjusted basis.

\footnotetext{
${ }^{1}$ See Mary Jo White, SEC Chair, on Oct. 16, 2015: "Examiners observed that some hedge fund advisers may not be adequately disclosing conflicts related to advisers' proprietary funds and the personal accounts of their portfolio managers. Examiners saw, for example, advisers allocating profitable trades and investment opportunities to proprietary funds rather than client accounts in contravention of existing policies and procedures."
} 
First, we find evidence that insider capital is deployed to less-scalable funds. Funds with more insider capital are smaller: one additional percent of inside investment is associated with a fund that is smaller by $\$ 7-10$ million. This result holds both unconditionally and within-firm. ${ }^{2}$ We also test the relationship between inside investment and fund scalability. Following the methodology employed by Yin (2016), which measures the decreasing return to scale by regressing style-adjusted returns against lagged assets, we find that funds with greater insider investment are also less scalable.

Second, we find that funds with greater insider capital are more likely to restrict outsider capital entry on both intensive and extensive margins. On the intensive margin, managers limit outsider inflows to the high-performing insider funds. On the extensive margin, insiders can strategically close capital access to outsiders entirely. The presence of funds closed to outside investors is a challenge for conventional models of delegated asset management, as managers are not capturing the entire surplus by forgoing the management fees earned on additional capital. Instead, we find that such funds strongly outperform, delivering $2-4 \%$ additional excess returns yearly. Such strong performance suggests that outside investors are in fact rationed from fund participation. Notably, such funds closed to outside investors are disproportionately funded by inside capital.

Third, we find that inside investment is an important predictor of excess returns when comparing different funds within firms, and within the same fund over time. Our panel regression controls for the Fama and French (1992) and Carhart (1997) factors, as well as the seven factors set out in Fung and Hsieh (2004), at the fund level. An increase in inside investment by a standard deviation within the same firm (across funds), and within the same fund (across time), is associated with annualized excess returns of $1.4-1.7 \%$. We confirm this finding in an event study that focuses on firms that create a second fund. In these cases, we find that the original fund outperforms when inside capital stays in this fund relative to when insiders move their capital to the newly-formed fund. These results suggest the possibility of "skimming" motives on the part of fund managers.

\footnotetext{
${ }^{2}$ By firms, we refer to the fund advisor-i.e., the company in charge of managing all funds within the family.
} 
We rule out natural alternate explanations for our results. A chief concern is the signaling issues associated with insider capital. We find that funds with greater insider capital accept less, not more, outside capital-including in other funds that are part of their families-which is inconsistent with a story that emphasizes the role of inside investment as a signaling tool or marketing strategy. We also find that funds with greater percent of investment funds take on less leverage and do not have assets with worse liquidity properties nor exhibit greater tail risk-suggesting that these higher returns are not compensation for some alternate forms of risk. Although we cannot fully rule out the relationship between inside investment and other fund attributes, understanding inside investment through the lens of fund capacity constraints appears to best explain our results.

Our key contribution is to document how hedge fund managers prioritize personal investments to less-scalable strategies, and subsequently restrict the scale of their funds, in ways that boost performance. This result connects closely with Yin (2016), who emphasizes the role of decreasing returns to scale among hedge funds, which managers seem not to fully internalize given their stated contract terms including management and performance fees. We document that a non-stated contract term and the presence of insider capital provides an important additional reason for fund managers to operate their funds at smaller scales. The impact of these personal stakes on outside investors is mixed: some investors are able to co-invest with insiders and earn superior returns due to smaller fund sizes and the alignment of interests. However, the smaller scale of insider funds can have detrimental consequences on other outside investors, who are rationed out of fund participation.

We also contribute to research on managerial ownership in the hedge fund industry. Agarwal, Daniel, and Naik (2009) finds a positive relationship between estimated managerial investment, based on the assumption that fee income is reinvested in funds, and subsequent fund performance. We extend this result and provide additional context by finding evidence for strategic allocation of private capital, as opposed to personal stakes which are increasing mechanically, and by establishing one key mechanism for the outperformance of insider funds: the choice of managers to limit outside capital investment on 
funds with greater private capital. ${ }^{3}$

Our results come with several important caveats. Though we establish inside ownership as an important predictor of excess returns and highlight the role for the strategic allocation and capacity constraints in understanding this result, it is possible that other channels operate in addition to the ones we emphasize. It is possible that inside investors are better informed about the skill of various fund managers, in ways that differ from fund scaling, and that they deploy capital accordingly. Alternatively, high-insider-investment funds may be less subject to agency conflicts and engage in superior research analysis, see Berk, van Binsbergen, and Liu (2017). Finally, it is possible that higher returns from high insiderinvestment funds are a proxy for some risk factors, unrelated to either the Fama and French (1992), Carhart (1997), and Fung and Hsieh (2004) factors. In light of these caveats, our paper provide a novel evidence to the literature examining fund families by showing that hedge fund managers allocate personal capital strategically across funds at the expense of crowding out outsider capital. 4

More broadly, our core results advance knowledge of the asset management industry by highlighting the role for inside investment as an incentive to alter managers' decisions to strategically allocate capital in ways that affect the returns and investment opportunities available to institutional investors. Further, this paper contributes to the literature on managerial earnings by emphasizing the unique role for returns on personal capital contributions as a component of overall managerial income in the hedge fund industry. ${ }^{5}$ We also contribute to the literature on diseconomies of scale by highlighting the novel incentives for more optimal fund scaling generated by non-contract features of managerial behavior in the form of private capital stakes. ${ }^{6}$

\footnotetext{
3Other papers analyze managerial investment at the firm level. Brown, Goetzmann, Liang, and Schwarz (2008), for instance, finds that hedge fund firms with concentrated ownership are related to lower performance and suggest possible agency conflicts driving these results.

4See Massa (2003), Sialm and Tham (2017), Berk, van Binsbergen, and Liu (2017).

5See Agarwal, Daniel, and Naik (2009), Burasachi, Kosowski, and Sritrakul (2014), Chen, Goldstein, and Jiang (2008), Ackermann, McEnally, and Ravenscraft (1999), Qiu, Tang, and Walter (2016), Ibert, Kaniel, Van Nieuwerburgh, and Vestman (2017), and Ozik and Sadka (2015).

${ }^{6}$ See Yin (2016), Ramadorai (2013). An important branch of this literature examines the role of liquidity and diseconomies of scale, such as: Chen, Hong, Huang, and Kubik (2004), Bris, Gulen, Kadiyala, and Rau (2006), and Yan (2008).
} 


\section{DATA}

Our dataset combines regulatory Form ADV filings with commercial hedge fund return series from HFR, eVestment, BarclayHedge, Eurekahedge, and CISDM. Form ADV is a required regulatory disclosure form used to register with both the Securities and Exchange Commission (SEC) and state securities authorities. Reporting under Form ADV is governed by the US Investment Advisers Act of 1940, as amended by Dodd-Frank. Disclosure requirements under this form have changed over the years. In the period from 1996-2011, funds with assets under management below \$25 million, or fewer than 15 clients, were generally exempt from registration. Hedge funds in this period frequently used complex fund structures to evade disclosure even when assets were above this threshold.

Private fund reporting increased in 2005, when the SEC went to court to force funds to count all investors as clients. Though courts ultimately struck down the SEC's interpretation, disclosure through Form ADV increased throughout this period. Our primary sample is formed after 2011, in the aftermath of changes in required disclosure imposed by DoddFrank. Under prevailing regulations, all investment advisors-including hedge funds-are now required to file a Form ADV with the SEC if they (1) reach a $\$ 100$ million threshold for assets under management for a typical fund, (2) reach a \$150 million threshold if the firm has only private clients, (3) have over \$25 million in assets and are not subject to examination in their home states (states that do not require examination currently include New York and Wyoming). Subsequent to their initial filing, firms must refile once a year (as long as their assets under management exceed \$25 million), or if there have been changes in material information since the last filing.

We obtain Form ADV from the SEC over the period 2011-2016. We link Form ADV information together with information on hedge fund returns obtained from a combination of five datasets: HFR, eVestment, BarclayHedge, Eurekahedge, and CISDM. We begin the merge with HFR, eVestment and BarclayHedge, which contain for many firms an SEC identifier common to both the commercial hedge fund datasets and Form ADV. If we do 
not have an SEC identifier, we next look for close matches (selecting only perfect matches) among firm and fund names in both datasets, after eliminating extraneous stop words and abbreviations.

In 2012, Form ADV was updated to include questions about the internal investment of their funds. We draw specifically on Section 7.B.(1), question 14 of Form ADV: "What is the approximate percentage of the private fund beneficially owned by you and your related persons." This question asks funds to disclose the percentage of investment stakes in the fund which can be attributed in ultimate ownership to "related persons."

Summary Table I shows basic summary information about our core Form ADV dataset taken from 2016, while Table II reports information on our merged sample. The broad ADV sample is able to establish key statistics about the overall size and scope of the entire hedge fund industry beyond prior work. Figure II demonstrates our merge rate across the range of firm ownership. We find that funds with complete inside investment $(100 \%)$ and no inside investment ( $\%$ \%) exhibit worse merge rates into our ADV dataset. These funds also pose additional identification questions-either outsiders cannot invest, or insiders have chosen not to invest in these funds. For these reasons, we focus the remainder of our analysis on funds in the interior of the internal investment distribution: between 1 and $99 \%$ inside investment, inclusive (our result are robust to their inclusion).

A breakdown of "related parties" is provided in Table III, which illustrates all possible configurations of which parties constitute related parties. The most common response is "Sponsor of GP,"7 suggesting that the definition of related party most often corresponds to a vehicle used by the actual managers or general partners of the fund. Alternately, related parties can include other closely-related entities, such as asset investment by a broker/dealer. A separate set of questions asks the legal name of all related parties: these entities are typically closely related to the management company, share a supervised person three-quarters of the time, and share a common physical office over half of the time.

\footnotetext{
7Appendix Table A1 examines our main analysis regressing inside investment against excess returns, focusing on the subset of funds with only GP investments as their related party.
} 
Despite the limitations of this measure in calculating managerial stakes exactly, we document that related parties are typically vehicles for fund investment by the general partners, and that they typically represent asset management on behalf of closely-related entities that can be considered "inside capital."

The inside investment data used in this paper is illustrated in Figure III. Panel A shows the density of responses on inside investment across our full merged dataset. Panel B shows the distribution of assets under management attributable to inside investment, shown on a log-dollar scale.

\section{Mechanism}

In this section, we outline the key possible mechanisms underlying the relationship between inside investment and fund performance, as predicted by our model. A full exposition of our model and implications can be found in Appendix A.

1. Size Performance Tradeoff: Our basic explanation for the role of inside investment as a predictor of cross-sectional fund performance relies on the tradeoff between managerial earnings through fee income on delegated asset management and returns on privately-invested capital. With limited commitment, managers cannot credibly commit to not increasing the size of their fund in the future to the point that the excess returns to investment strategies are driven down to zero. Personal capital commitments better align the incentives of managers and outsiders, providing greater incentives for managers to scale their funds less aggressively in a manner which results in greater returns to investors-but at the cost of capital participation by other outside investors.

2. Preferential Treatment: Another possibility is that managers allocate additional attention or trade differently for funds which have greater amounts of insider capital. While our main proposed explanation highlights one aspect of this dynamic - the ability for managers to preferentially manage fund size for funds managing insider capital-managers may also potentially change other attributes of these funds. These 
include allocating additional attention, allocating superior managers, or executing superior trading strategies. Funds may take different risks on funds managing insider capital than on funds managing the capital of outside investors.

3. Superior Information: An alternate and complementary explanation for the relationship between inside investments and fund performance is that inside investors are simply better informed about managerial ability within the fund family, and they allocate their capital to the better fund managers.

4. Signaling: A potentially offsetting role for managerial capital allocation relies on the role of public signaling. Fund managers, particularly for less-established funds, may need to use inside capital commitments in order to convince outside investors of fund quality. When managers are required to hold costly private stakes in order to demonstrate quality and earn management fees on outside capital, inside investment could potentially predict flows but would be a poor predictor of fund performance. As Form ADVs are commonly used by outside investors to assess fund quality, managerial stakes in this context reflect verifiable and costly personal commitments.

These channels need not be mutually exclusive-for instance, the greater the role of moral hazard or risk-shifting effects in driving managers to exert effort or allocate trades based on inside capital investments, the more private information there will be regarding the success of different funds within a firm.

\section{EMPIRICAL STRATEgY}

\section{III.A Excess Return Measures}

Throughout our empirical tests, we use three different excess return measures. First, we run a return regression, taking as our benchmark the Fung and Hsieh (2004) Seven-Factor 
model:

$$
\begin{aligned}
r_{i t}^{e} \equiv r_{i t}-r_{f t} & =\alpha_{i t}+\beta_{1, i} S \& P_{t}+\beta_{2, i}(S C-L C)_{t}+\beta_{3, i} 10 Y_{t}+\beta_{4, i} \text { CredSpr } \\
& +\beta_{5, i} B d O p t_{t}+\beta_{6, i} \text { FXOpt }_{t}+\beta_{7, i} \text { ComOpt }+\varepsilon_{i t} \quad i=1, \ldots, N
\end{aligned}
$$

The Fung and Hsieh (2004) factors are widely used in hedge fund research, including Fung, Hsieh, Naik, and Ramadorai (2008) and Patton and Ramdorai (2013). ${ }^{8}$

We also consider the Fama and French (1992) and Carhart (1997) Four-Factor model, which is more commonly used in mutual fund research:

$$
r_{i t}-r_{f t}=\alpha_{i t}+\beta_{1, i} R M R F_{t}+\beta_{2, i} S M B_{t}+\beta_{3, i} H M L_{t}+\beta_{4, i} M O M_{t}+\varepsilon_{i t} \quad i=1, \ldots, N .
$$

The factor exposures allow us to compute an average excess return $\alpha_{i t}$ for each month and fund, shown here for the Fama-French and Carhart Four-Factor model (comparably, we estimate a Fung and Hsieh (2004) excess return $\alpha_{i t}^{F H}$ ):

$$
\alpha_{i t}^{F F C}=r_{i t}^{e}-\hat{\beta}_{1, i} R M R F_{t}+\hat{\beta}_{2, i} S M B_{t}+\hat{\beta}_{3, i} H M L_{t}+\hat{\beta}_{4, i} M O M_{t} \quad i=1, \ldots, N .
$$

The third return measure we consider is the a Style-Adjusted-Return measure, following Yin (2016):

$$
\text { Style-Adjusted-Return }_{i t}=r_{i t}-\frac{1}{S_{k}} \sum_{j=1}^{S_{k}} r_{j t} \quad i=1, \ldots, N, S_{k} \in \text { strategies. }
$$

The above specification differences the return earned by a fund for a given period against the average return of all funds of the same style during the same period. This specification is used for ease of calculation from raw returns, and for its ability to adjust for the risk associated with different investment strategies.

\footnotetext{
${ }^{8}$ These factors are: 1) an equity market factor-the S\&P 500 Index monthly return (S\&P); 2 ) A size-spread factor-the Russell 2000 Index monthly return, S\&P 500 (SC-LC); 3) a bond market factor-the monthly change on the 10-year Treasury constant maturity yield (10Y); 4) a credit spread factor-the monthly change in the Moody's Baa yield, 10-year Treasury constant maturity yield (CredSpr); 5) a bond trend-following factor (BdOpt); 6) a currency trend-following factor (FXOpt); and 7) a commodity trend-following factor (ComOpt). Additional details on the factors can be found at: http://faculty.fuqua.duke.edu/ dah7/DataLibrary/TF-FAC.xls.
} 


\section{III.B Inside Investment and Fund Scalability}

We test the relationship between excess returns and scalability of the hedge fund, following Yin (2016):

$$
r_{i, t}^{e}=\beta \cdot \log \left(A U M_{i, t-1}\right) \times \text { High Ownership } \text { H,t-1 }+\mathbf{X}_{\mathbf{i}, \mathbf{t}-\mathbf{1}}^{\prime} \Theta+\varepsilon_{i t} .
$$

In the above specification, we test three different dependent variables: (i) the return in excess of the style average (following Yin (2016)), (ii) Fama-French-Carhart, and (iii) Fung-Hsieh factor models. Our variable of interest is the coefficient $\beta$, from the interaction term between $\log \left(A U M_{i, t-1}\right)$ and High Ownership ${ }_{i, t-1}$, an indicator variable taking the value of 1 if the funds insider ownership is greater than the sample median. We control for $\log \left(A U M_{t-1}\right)$ to take into account the general decreasing returns to scale for all funds. Other controls in $\mathbf{X}$ include $\log \left(\right.$ total firm $A U M_{t-1}$ ), percent AUM Flow $w_{t-1 \rightarrow t}$, performance fee, management fee, an indicator for a high water mark, log(minimum investment), redemption period, fund age, whether the fund is open to new investment, and leverage. We

include fixed effects for the firm, year, and strategy, and cluster at the fund level. All flow and return measures are winsorized at the $1 \%$ level.

\section{III.C Inside Investment and Size}

To test for the relationship between ownership and size, we also perform a comparable analysis regressing the assets under fund management against the fraction of inside investment:

$$
A U M_{i t}=\psi \text { Ownership }_{i t-1}+\text { Firm }_{i}+\text { Year }_{t}+\varepsilon_{i t} .
$$

The $\psi$ coefficient here captures the relationship of size and fractional inside investment within firm and year. 


\section{III.D Fund-Flow Sensitivity and Return Predictability}

Following prior literature, such as Chevalier and Ellison (1997), we define fund flows using net flows $r_{i t}$ as:

$$
\text { Flow }_{i t}=\frac{A U M_{i t}-\left(1+r_{i t}\right) \cdot A U M_{i, t-1}}{A U M_{i, t-1}} .
$$

Using this definition, we also test standard fund-flow sensitivities:

$$
\begin{aligned}
\text { Flow }_{i t} & =\eta \text { High Insider Ownership } \\
& +\beta_{i t-1}+\beta_{1} \alpha_{i t-1} \times \text { High Insider Ownership }_{i t-1} \\
& +\delta_{1} \alpha_{i t-1}+\delta_{2} \alpha_{i t-2}+\delta_{3} \alpha_{i t-3}+\mathbf{X}_{\mathbf{i t}-\mathbf{1}}^{\prime} \Theta+\text { Firm }_{i}+\text { Year }_{t}+\varepsilon_{i t} .
\end{aligned}
$$

In flow specifications, time is measured quarterly. Other controls in $\mathbf{X}$ include leverage, lagged fund size, management fees, performance fees, redemption period, high watermark, lagged flows, fund formation, and strategy fixed effects. ${ }^{9}$ The key coefficient of interest is $\beta_{1}$ : whether funds with high inside ownership (defined as inside investment above the median) exhibit less flow-performance. Lower flow-performance would indicate when funds with greater inside investment accept less additional funding in response to better prior performance.

\section{III.E Inside Investment and Performance}

We next test whether inside investment results in greater risk-adjusted fund-level returns. Accordingly, we adopt a two-step approach. In the first step, we estimate a timeseries regression of excess returns on factor exposures, as discussed in Section III.A. In the second step, we consider both a panel regression (which allows us to control for firm and year fixed effects) as well as a standard Fama and MacBeth (1973) cross-sectional regression which relates excess returns from fund-specific factors to inside ownership and other

\footnotetext{
${ }^{9}$ Following Getmansky, Liang, Schwarz, and Wermers (2015).
} 
variables. A summary of the main dependent variables used in our analysis can be found in Table IV.

In this specification, we consider excess returns $\left(r_{i t}-r_{f t}\right)$ to be the net returns after fees minus the risk-free rate, as we take the standpoint of an institutional investor interested in allocating across the broad investable universe of fund managers. ${ }^{10}$ This monthly timeseries analysis is run for each of $N$ funds in order to generate fund-specific factor loadings.

We note important data limitations associated with commercial hedge fund return series which we do our best to address. As has been noted in prior research, funds retain discretion on reporting their returns (see: Bollen and Pool (2008), Bollen and Pool (2009), Jorion and Schwarz (2014), and Patton, Ramadorai, and Streatfield (2015)). We restrict our sample to funds for which we have at least 24 months of data, excluding the first 24 months of data to avoid incubation bias, and we also require funds to have at least \$20 million in gross asset value. We exclude fund-of-funds because their inside investment is relatively limited, and the scope for investment is radically different. ${ }^{11}$ We also exclude funds with either o or $100 \%$ inside ownership. We find that funds with complete inside investment $(100 \%)$ and no inside investment $(0 \%)$ exhibit worse merge rates into our ADV dataset. These funds also pose additional questions-either outsiders cannot invest, or insiders have chosen not to invest in these funds. For these reasons, we focus the remainder of our analysis on funds in the interior of the inside investment distribution: between 1 and $99 \%$ inside investment, inclusive. ${ }^{12}$

With the monthly estimates of risk-adjusted returns, we estimate (following Fama and MacBeth (1973)) cross-sectional regressions against fund characteristics, including our measure of ownership:

$$
\alpha_{i t}=\phi+\gamma \text { Ownership }{ }_{i, t-1}+\mathbf{X}_{\mathbf{i}, \mathbf{t}-\mathbf{1}}^{\prime} \Theta+\varepsilon_{i t} .
$$

\footnotetext{
${ }^{10}$ Our results also hold when we regress against gross returns, adding fee income back in.

${ }^{11}$ Because fund-of-funds invest in other investment vehicles, rather than underlying securities, we do not expect the same patterns of diminishing returns. We also expect flow-performance and return persistence to work very differently with these investment advisors.

${ }^{12}$ Our analysis is robust to the inclusion of funds with zero or $100 \%$ inside ownership, the inclusion of fund-of-funds, and the inclusion of smaller funds.
} 
The key variable of interest is $\gamma$, which captures the predictive role of greater inside investment on excess returns. To measure ownership, we use both the percentage of the fund that consists of insider investment (our preferred measure) as well as the gross insider exposure. This measure of ownership is drawn from annual ADV forms, and it represents the ownership stake from the prior year. Additional controls in $\mathbf{X}$ include controls for fund age, size, and strategy.

Though standard in the mutual fund literature, a key limitation of the Fama and MacBeth (1973) cross-sectional specification is that it does not allow us to control for time and firm fixed effects. To do so, our baseline specification is a panel regression of fund and firm characteristics against excess returns:

$$
\alpha_{i t}=\phi+\gamma \text { Ownership }_{i, t-1}+\mathbf{X}_{\mathbf{i}, \mathbf{t}-\mathbf{1}}^{\prime} \Theta+\text { Adviser }_{i}+\text { Month }_{t}+\varepsilon_{i t} .
$$

The fixed effects for adviser include (depending on the specification) firm fixed effects (capturing the effects of moving from one fund in a family to another with greater inside investment), or fund fixed effects (using the time-series variation of inside investment, within the same fund; holding equal all other time-invariant fund characteristics). Therefore, in this specification: our key coefficient of interest, $\gamma$, captures the impact of inside investment, either as percentage of fund as well as gross exposure, on excess return relative to another firm/fund in the same family and month with less inside investment. This allows us to control for all other invariant firm, fund, and time characteristics which might otherwise drive excess returns. Standard errors are clustered at the month level, following Petersen (2009). ${ }^{13}$ We also extend our analysis to consider return smoothing motivations, which have been documented for hedge funds, e.g. by Getmansky, Lo, and Makarov (2004).

\section{Results}

The following subsections tests three hypotheses predicted by our framework: first, hedge fund managers allocate their insider capital to their less-scalable strategies; second,

\footnotetext{
${ }^{13}$ Our results are robust to double-clustering at the fund and month level.
} 
insiders restrict access to outside investors in these funds; and third, insider funds, as a consequence, outperform on a risk-adjusted basis.

\section{IV.A Strategic Allocation of Inside Investment}

\section{IV.A.1 Fund Scalability and Inside Investment}

We first establish that hedge funds face decreasing returns to scale for funds with high GP capital investments, or insider investments. We establish this by using a similar approach as Yin (2016): by regressing excess returns against asset flows and fund-level ownership.

The results in Figure IV estimate equation 5 for specialized arbitrage strategies. This figure plots the coefficient of the interaction between lagged assets and high insider funds against style-adjusted returns. Negative coefficients suggest that high-insider funds are less scalable, because higher fund assets predict more negative returns. We find that insider capital is, in fact, allocated in general to funds with more decreasing returns to scale strategies. We also contrast our results across different types of strategies. We find more negative coefficients in categories such as event-driven and relative value, which are typically associated with lower scalability due to liquidity, price impact, and limited float. We find that insider capital is even more tightly matched to decreasing returns to scale strategies in those categories.

The interpretation of these results is that when insider funds experience larger assets under management, the excess returns to investors deteriorate more significantly relative to outsider funds. This result holds whether we examine excess returns using a style-adjusted average, as in Yin (2016), or whether we use the Fama-French or Fung-Hsieh factor models.

\section{IV.A.2 Fund Size and Inside Investment}

We next establish the strategic aspect of managerial investments in their own funds through analyzing the role of size and inside investment. As a reminder, our framework 
hypothesizes that a key mechanism driving the superior performance of insider funds is their smaller size, due to decreasing returns to scale in investment technologies.

We confirm that insider funds tend to be smaller, in line with the mechanism of our framework. In Table $\mathrm{V}$, we regress the size of the fund against inside investment. In column 2 of Panel A, we focus on our matched dataset and find that an additional percent of inside investment is associated with a fund that is smaller by $\$ 4-8$ million. This relationship persists when we examine a specification where the dependent variable is the log of assets under management in columns $3-4$.

To address concerns about biases in the merged dataset, we retest this specification on the Form ADV dataset only and present the results in Table V, Panel B. These specifications use the field "Gross Asset Value" derived from fund-level information in Form ADV. Gross asset value differs from assets under management in that it does not subtract out the value of short positions from the portfolio, and so it overestimates true fund size. Despite the limitations of this measure, using this field as a dependent variable enables us to avoid losing observations on the merge between our Form ADV dataset and the commercial hedge fund datasets. The results are very similar when not restricting on funds that merge into commercial hedge fund datasets: we find in column 2 that within a firm, funds with an additional percent of inside investment are around \$10 million smaller in gross asset value. These results provide additional support for our main hypothesis: inside investment funds are smaller, suggesting that managers are less likely to hit the limits of the capacity constraints of their investment strategy when their own private capital is deployed.

We examine other possible determinants of inside investment, reporting the results in Appendix Table A2. In this specification, we run a yearly panel regression of inside investment against a variety of fund and firm characteristics. We begin in column 1 with a regression of the percentage of fund assets attributable to investments by insiders and related parties against a number of fund and firm characteristics without additional fixed effects. Standard errors are clustered at the firm level. We then add fixed effects for fund inception year, firm, and year of observation. 
The most robust correlate of inside investment remains fund size: high inside investment funds are smaller. We also find that leverage is negatively associated with inside investment once we control for firm fixed effects. One interpretation to the risk explanation is that skilled managers facing capacity constraints may simply prefer to avoid all outside money (both debt and equity) in select funds, in which they prioritize allocations of their own private capital. For this reason, they may simply prefer to avoid accepting additional assets under management as reflecting debt claims. ${ }^{14}$

There is weak evidence that fees-particularly performance fees-are associated with higher inside investment, though this relationship is generally small in magnitude and not statistically significant once we add firm fixed effects. Though our basic approach assumes that managers and investors take fees as given, one possible reason to consider the endogenous determination of fees might be that insiders use higher fees to further ration out investors in funds with greater levels of inside investment. However, the key predictions of our framework - that inside investment will be associated with higher post-fee alpharemains as long as we assume that managers cannot fully set fees to maximize all of the investor surplus. Fees appear to be sticky, do not exhibit substantial cross-sectional or timeseries variation, and are not robustly associated with inside investment once we control for other variables.

\section{IV.B Capital Rationing and Inside Investment}

We next test whether GP capital is allocated into less-scalable funds and will be most valuable when managers are able to also restrict outside capital entry into these funds. We first consider how lagged excess returns relate to asset flows to funds.

Figure V plots a non-parametric relationship between lagged returns and fund inflows by funds with a greater or lesser degree of insider investment measured at a quarterly frequency. Insider funds are defined as those with a greater-than sample average amount of fraction of fund assets attributable to insiders. ${ }^{15}$

\footnotetext{
${ }^{14}$ We thank a referee for making this point.

${ }^{15}$ For all flow-based analysis, we exclude eVestment from our sample due to unreliable NAV information from this data provider.
} 
This figure illustrates that outsider funds exhibit a standard fund flow-performance relationship as documented in prior research on hedge funds and mutual funds. ${ }^{16}$ However, insider funds demonstrate a different profile: insider funds that experience positive excess returns do not exhibit as subsequently high inflows, consistent with the idea that high-performing funds with greater insider capital manage funds operate closer to their optimal size by restricting inflows by outsiders after positive returns.

The fact that high-inside-investment funds do not attract higher inflows is strong evidence in our setting against signaling-based explanations of the role of inside investment. If personal stakes by managers were necessary to attract additional capital, we would expect that funds with greater inside investment might attract additional funds-particularly when prior returns were high. Instead, we find that high-inside-investment funds do not scale up as much as outsider funds when returns are high. These results point to a role for moral-hazard explanations for why inside investment is associated with superior performance.

Additionally, we find little evidence that insider funds feature greater capital stabilitywe do not see strong evidence that poor returns are followed by lower outflows among insider funds relative to funds catering to outside capital. This evidence suggests that insider funds are not characterized by a longer horizon to wait out poor returns, offering funds a more patient source of capital, or the limits of arbitrage (Shleifer and Vishny, 1997).

Table VI presents additional flow performance specifications to test possible signaling explanations, as outlined in equation 8 . The dependent variable in these specifications is the percent flow, or an indicator whether inflows are positive. A variety of other controls are included in these specifications. ${ }^{17}$ We find in column 1 that greater lagged excess returns predict lower flows among funds with greater inside investment, suggesting that insider funds do not accept as much flow in response to positive returns. Column 2 of this table highlights the extensive margin and suggests that funds with greater inside investment are

\footnotetext{
${ }^{16}$ See Chevalier and Ellison (1997), Sirri and Tufano (1998), Getmansky, Liang, Schwarz, and Wermers (2015).

17These include leverage, management fees, number of redemption days, high watermark, lagged flow, and the log of gross asset value (lagged one year).
} 
also much less likely to accept any additional inflows at all in response to past superior performance.

The remaining columns of this table expand our analysis to the other funds within the family. We do so to test a broader class of signaling explanations-perhaps funds operate certain "flagship" funds to an optimum scale in order to advertise returns. If this is true, we might expect that returns do not predict flows for some high insider funds (because managers are using these funds to advertise high returns) - but signaling stories would predict that foregoing additional fee income today (to produce better returns for marketing) should be followed up with higher inflows in the future, perhaps in other funds, generating future fee income.

In columns 3-4, we find little evidence that lagged excess returns drive flows to other funds in the family, measured at either the extensive or the intensive margin (whether inflows are positive). In columns 5-6, we restrict our attention to high ownership funds. For this subset, as well, we find little evidence that high returns drive inflows to other funds in our family. Investors appear to distinguish between different funds in the family when allocating capital, and to preferentially increase flows only to the funds that directly outperform. As a result, we do not find evidence for the idea that managers may want to leave personal capital in some funds in order to signal their quality, thus driving flows (and management fees) to other vehicles they manage. While this finding does not fully rule out a signaling explanation for our results, the bulk of the evidence is more consistent with a moral hazard view.

To further explore the role of active capital rationing, we focus on a sample of funds for which we are able to establish the role of managerial discretion in accepting capital. In Table VII, we examine funds which are explicitly closed to outside investors as reported by commercial databases. In columns $3^{-6}$ of this table, we find strong evidence that funds that are closed to outside investors strongly outperform on a factor-adjusted basis. In these specifications, we regress a dummy variable for funds open to investors against excess returns measured using a four- or seven-factor model, finding that funds closed to outside 
investors outperform by $0.23-0.45 \%$ each month, corresponding to $2-4 \%$ a year in excess returns.

Funds which do not accept additional inflows are able to generate superior performance. These excess returns suggest that outsiders would like to enter these funds and are being actively rationed out of them. The presence of these funds, however, poses a challenge for traditional views of delegated asset managers-why do managers forgo management fees by not accepting outside investors into these funds?

A potential resolution to this puzzle is suggested in columns 1-2 of Table VII. In these specifications, we examine the relationship between inside investment and funds that are open to investors. We find that funds which are closed to investors are substantially more likely to have a greater concentration of inside investment.

These results highlights managerial capital rationing as a mechanism to explain the outperformance of insider funds. Managers restrict the participation of outsider investors both on the intensive margin, but restricting inflows to insider funds that outperform, and on the extensive margin, by prohibiting outsider capital entry entirely on some highly outperforming funds. The superior performance of these insider funds does not drive inflows to other funds within the family, which points to the role of moral hazard as a key driver of the relationship between inside investment and fund returns.

\section{IV.C Inside Investment and Fund Performance}

The analysis so far has analyzed how managers allocate private capital to funds with more decreasing returns to scale and optimize the size of such funds. In this section, we build on this analysis to explore the implications of this capital scaling on the returns experienced by outside investors.

\section{IV.C.I Cross-Sectional Relation}

Our framework predicts that within a firm, funds with a greater proportion of inside capital will outperform, because managers will allocate their least-scalable strategies to 
funds managing their money, and further will internalize the capacity constraints of the investment strategy when accepting new capital. Funds with greater inside capital retain greater alpha, in equilibrium, because managers maximize profits by not accepting additional outside capital beyond the capacity limit of the investing strategy.

In our main specifications, we use a two-step approach to control more closely for fund factor exposures. We analyze the role of inside investment on risk-adjusted returns. Panel A of Table VIII presents a panel specification, using as the key regressor the percent of a fund's asset under management that can be attributed to insider investment in the prior year against excess returns. In columns 1-3, we measure excess returns using a sevenfactor model in the first stage, and we show the results of a second-stage regression of inside investment against excess returns. Columns 4-6 measure excess returns using the Fama-French and Carhart Four-factor model instead. ${ }^{18}$

Specifications (1) and (4) in this table shows impact of lagged inside investment on excess returns, including a control only for size. Specifications (2) and (5) add controls for fund characteristics (fund inception year and strategy), as well as a firm fixed effect. This ensured we are comparing two funds within the same fund family. Both sets of specifications suggest large positive, and statistically significant effects of inside investment on fund performance. Our preferred specifications, in columns (3) and (6), replace the fund controls and the firm fixed effect with a fund fixed effect. This controls for all fundinvariant characteristics; using the time-series variation in inside investment within funds. Our estimates in that column suggest that a fund with a $1 \%$ increase in inside investment experiences a $0.54^{-0.66}$ basis point higher excess return per month, depending on whether we use the Fama-French and Carhart or the Fung-Hsieh factor correction.

Scaling our results, we find a $1.4-1.7 \%$ increase in alpha per year for a fund with a standard deviation increase $(22 \%)$ in the amount of inside investment relative to another fund in the same firm with similar characteristics in the same year. These results are

\footnotetext{
${ }^{18}$ To better understand the underlying risk exposure behind these numbers, in Appendix Figures B.2 and B. 3 we plot estimated factor exposures for both sets of models; meanwhile, Appendix Figure B.4 shows the correlation between risk factors and inside investment.
} 
both economically and statistically significant and suggest a strong importance for internal investment as a predictor of cross-sectional fund performance. The larger magnitude and significance of results when controlling for both firm and fund fixed effects suggests the importance of discretionary fund allocation by insiders: there is high dispersion of fund returns within firms in our sample, and insiders choose which investment strategies to pursue for which funds, as well as which funds to invest in. Our results suggest that inside capital is more likely to be deployed in funds that outperform others within the family.

We also find a strong role for inside investment in Panel B of Table VIII, in which we examine the gross amount of inside investment, rather than the fractional amount, while also controlling for size and other fund-level characteristics. These results make a series of sample restrictions outlined in the section above. ${ }^{19}$

In a robustness Table A4, we also examine a Fama-MacBeth cross-sectional regression. In this specification, as outlined above, we do not control for firm or year fixed effects. However, we also find comparable results in these specifications across both the sevenfactor and four-factor models, illustrating the robustness of our result: that greater inside investment is associated with superior performance.

\section{IV.C.2 Event Study: Skimming}

The results from the previous section provide strong evidence of a role for insider investment in driving fund returns. This raises the possibility that investments by insiders are a critical component of the earnings for managers, alongside management and incentive fees. Further, it is possible that fund managers may seek to further take advantage of this relationship by steering clients into lower-performing funds.

We explore this possibility in Figure VI, which conducts an event study in the aftermath of the creation of a new fund among firms which previously only had one fund. The creation of an additional fund presents two possibilities for fund managers: (i) they can

\footnotetext{
${ }^{19}$ To test for robustness of these restrictions, in Appendix Table A3 we include funds with o or $100 \%$ inside investment. We find comparable results in these samples. We have also verified, in results available upon request, that our results hold using a value-weighted measure.
} 
either keep their internal capital invested in the original fund, using the new fund to attract new capital, or (ii) they can shift their own capital to the new fund, and market the original fund to investors. If the amount of insider capital is an important determinant of fund performance, we expect different fund performance in the original fund under the two cases. If managers are shifting their capital outside of the fund, we expect the performance of the original fund to deteriorate, since managers are no longer as invested in success of the fund. If, on the other hand, managers keep their capital in the original fund, the performance of the original fund should remain strong.

To test this possibility, we focus on all cases in which a hedge fund which previously only operated one fund opens a new, second, fund. We isolate two cases: one in which the new fund has less internal investment than the original, the new fund has "low inside investment," and another in which the new fund has more internal investment than the original. We plot cumulative returns of the original fund for the two-year window both before and after the fund creation date. We track the returns on the original fund to avoid the issue of incubation bias (Evans, 2010) which would be posed by analyzing the returns of the newly-generated fund.

Our results suggest that fund performance is relatively similar before the event date for the original fund, regardless of whether the firm subsequently creates a new fund with high or low internal investment. Differences grow more pronounced in the aftermath of fund creation. We find that when the new fund has "low inside investment" — suggesting that managers keep their internal capital in the original fund-fund performance suffers relative to when the newly formed fund has "high inside investment." We expect to see this difference because managers are more invested in the success of the initial fund if their capital remains deployed in the fund. If their own capital has moved to a different fund, performance tends to suffer in the window after fund creation. ${ }^{20}$

Though these results are not fully conclusive, they are suggestive of the possibility of "skimming" motives on the part of fund managers. If managers are able to shift their

\footnotetext{
${ }^{20}$ In a difference-in-difference regression, the interacted term of High Inside $\times$ Post has a coefficient of 0.969 and a standard error of 0.214 , which is significant at the $1 \%$ level.
} 
internal investments across funds within the same family, they seem to be able to focus their investments on successful funds, while steering outside capital into the lower-performing funds. These results provide additional context to our discussion of mechanisms in Section II and previous empirical results suggesting that active decisions made by fund managers regarding fund creation and capital deployment play a role in determining returns for outside investors.

To be clear, this analysis does not identify whether this is due to insiders having better information on which fund managers can outperform relative to outsiders, or because managers devote more effort when greater amounts of personal capital are on the line. Despite the multiple possible explanations, we emphasize that our result provides novel evidence on the role of inside investment in shaping fund performance as new funds are created.

\section{IV.D Robustness Tests}

The previous results are subject to several important caveats. Firstly, while these results suggest that fund-level inside investment predicts superior excess returns, the relationship might not be causal. It may well be that our measure of inside investment is a proxy for other fund-level characteristics. Another important caveat is that we are not able to fully control for whether our results are driven by some element of risk or instead result from agency conflicts within the firm. Despite our attempts to control for risk using the benchmark fund factors, it is also possible that the outperformance of high inside-investment funds occurs due to a novel risk factor. To further analyze the mechanisms driving our main result, we examine fund decisions along other dimensions.

\section{IV.D.1 Alternative Risks Explanation}

One possible caveat to our analysis is that superior performance in insider funds may reflect uncontrolled risk exposures. To account for this, we explore two other measures of 
liquidity and tail risk, as emphasized in the hedge fund industry (see Teo (2011), Agarwal, Arisov, and Naik (2015), and Agarwal, Ruenzi, and Weigert (2017)).

In Panel A of Figure VII, we explore the relationship between our measure of inside investment and the Getmansky, Lo, and Makarov (2004) liquidity measure. This approach uses an indication of autocorrelation in returns to estimate the extent to which return series are smoothed, hence providing a measure of asset liquidity, with higher numbers indicate greater asset liquidity. While we cannot reject equality across the distribution of inside investment, we find that, if anything, funds with lower inside investment have lower values of the smoothed index-indicating that their holdings have a higher autocorrelation, suggestive that they are holding less liquid instruments. Despite the imprecision, we can rule out the possibility that high inside investment funds are holding less liquid securities, at least as judged by the autocorrelation of returns using this metric.

In Panel B of Figure VII, we explore an alternate measure of performance-the maximum drawdown. This measures the greatest percentage loss the fund has experienced, relative to the maximum asset value, thus providing an estimate of tail risk. We plot average maximum drawdown for funds by each percentage of inside investment, and we also find no statistically significant relationship between inside investment and tail risk. However, there is a slight positive relationship between the extent of the maximum drawdown and inside investment-which could potentially suggest that hedge fund managers prefer to take risks with their own private capital which yield excess return in exchange for a small probability of extreme losses. Despite the plausibility of this mechanism, we emphasize that we find little statistically robust evidence that high inside investment funds are systematically engaging in strategies characterized by greater tail risk.

\section{IV.D.2 Heterogenous Treatment Effects}

As suggested by Getmansky, Liang, Schwarz, and Wermers (2015), investment styles face different capacity constraints. If capacity constraints are driving our main effect, we would also expect a heterogenous treatment effect across different investment styles. 
Specifically, investment styles that face larger capacity constraint frictions would have a stronger relationship between inside investments and excess returns.

Testing the relationship between inside investment and excess returns, we bucket by investment styles and present the results in Figure VIII, as in column 2 of Panel A Table VIII. Panel A of this figure plots the coefficient of inside investment against excess return by fund categories, as measured in our set of commercial hedge fund datasets. The main effects are driven by funds that engage in specialist absolute return strategies, arbitrage strategies, and equity funds. Within equity funds, in Panel B, the effects are driven by long-short funds. These fund strategies also plausibly feature capacity constraints in their investment strategies. By contrast, effects are insignificant among fund-of-funds and CTAs, which are typically associated with greater capacity.

We additionally test our main result across the distribution of inside investment. As shown by the quantile regression in Figure B.5 in the Appendix, our results are largely being driven by funds with higher levels of inside investment: those funds for which inside capital provides a substantial component of the capital base, for which we expect to see the highest-powered incentives. ${ }^{21}$ In Appendix Table A6 we examine our basic regression across different fund size levels, finding significant effects for the top two fund size quantiles, corresponding to fund sizes of at least \$126 million. ${ }^{22}$

\section{IV.D.3 Mechanical Capital Contributions}

Next, we examine the possible mechanical relationship between capital contributions from fee income. In Appendix Table A5, we first impute a "mechanical" component of personal capital contributions derived from rolling over prior fee income from the observed

\footnotetext{
${ }^{21}$ Our findings are weaker if we exclude high inside-investment funds from our sample. When we impose a \$50om cutoff and restrict to funds with inside investment of $<50 \%$, we find similar results as in the analysis in Kruttli, Monin, and Watugala (2019) based on a linkage of Form PF-ADV. However, our focus is on the larger universe of hedge funds, including those smaller funds not required to file Form PFs and those funds with substantial inside investment stakes.

${ }^{22}$ We also examine our results separately for funds with inception years prior to 2011 and funds started afterwards, examining the hypothesis that funds originated more recently might be more subject to signaling effects. We do not find evidence for a statistically significant difference between these two groups.
} 
inside investment, attributing the residual as reflective of managers' discretionary capital contributions. We find that even after subtracting this mechanical inside investment potentially resulting from rolled over fees, the discretionary component remains a large and statistically significant driver of fund returns.

\section{IV.D.4 Firm-Level Ownership}

We also investigate the implications of dispersion in firm-level ownership and its relation with fund-level inside investments. As shown in the Appendix, Table A7, column 3 suggests that inside investment at the fund level remains a significant predictor of excess returns, even when controlling for measures of firm-level ownership. In addition to fund-level inside investment, we find that the number of equity owners, as a measure of the dispersion in a hedge fund family's ownership structure, negatively predicts excess returns. While this result would be consistent with the idea that dispersion in a firm's equity structure is a sign of agency frictions and internal firm conflict, other explanations might also explain the relationship between the dispersion in firm-level equity ownership and fund performance. Despite the limitations of our measures of firm-level equity, we emphasize that our paper is the first to our knowledge to examine measures of insider capital allocations for a comprehensive sample of hedge funds at both the level of fund allocation as well as firm-level equity contributions.

\section{IV.D.5 Market Timing of Fund Managers}

An alternate and complementary mechanism in explaining our main result, that greater insider investment predicts higher excess returns, is that managers have superior private information about the abilities of funds than do outside investors, and so time the market by deploying personal capital to these funds. To test this hypothesis, we estimate the following specification in Table IX:

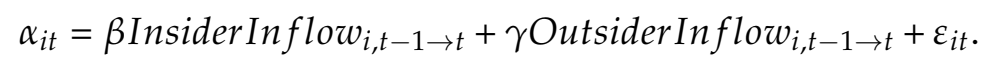


This specification tests whether changes in insider investment predict excess returns. Our test finds that changes do not predict excess returns in either inside or outside flows. While this test is not fully conclusive regarding the channel of superior inside information, this result suggests that insiders do not appear to be able to time their capital allocation decisions in ways that predicts future excess returns. Put differently, levels of inside investment, rather than changes in investment, predict future returns. In conjunction with the results on fund flows and performance, this result is perhaps unsurprising: fund insiders appear to frequently extract assets from their best-performing funds, rather than further investing, in order to continue to operate funds further from their capacity constraint and gain excess returns.

\section{CONCLusions}

A hedge fund manager's ability to access and allocate capital to profitable-but highly limited-investment opportunities within the funds they oversee is a substantial element of fund manager earnings. However, the managers' discretion to choose which of their funds to invest in, and the effect of their decisions on access to limited arbitrage opportunities, has rarely been empirically explored.

Our paper highlights the tension produced by the incentives resulting from inside investment. Firstly, we document the strategic nature of GP capital investments into their own funds and find that managers invest in their least-scalable strategies. Secondly, we find that managers also limit outsider capital access into their insider funds, sometimes closing access to outside investors completely. The consequence of these managerial capital decisions (on both outside and inside capital) is that insider funds substantially outperformbut are offered on a limited basis to outside investors.

From an outside investor's perspective, a positive feature of managers' having "skin in the game" is the usual alignment of incentives that improves their returns. Funds with higher internal investment have greater excess returns, even when we control for firm 
and fund fixed effects. They do so by taking on less leverage and less exposure to asset illiquidity, suggesting that hidden risks are not driving this result. Our results are large in magnitude, and they suggest that a fund with a one-standard-deviation increase in inside investment relative to the mean will provide an additional $1.4-1.7 \%$ of excess returns, annually.

This improvement in return performance comes at the cost of reduced fund participation by outsiders. We find evidence consistent with the idea that greater inside investment incentivizes managers to better manage the size-performance tradeoff in ways that crowdsout outside capital. High-insider investment funds are less likely to accept inflows in response to positive returns and are more likely to be closed to outside investors entirely. Additionally, we find evidence for strategic capital allocation at the time of new fund creation. When internal assets are shifted to newly-created funds, the original fund tends to underperform relative to the case when managerial commitments remain with the original fund. However, high returns on insider funds do not drive inflows to other funds in the family, suggesting that signaling motives cannot entirely explain our results. The joint relationship between internal investment, fund flows, and performance suggests that funds better manage capacity constraints when managers have personal capital at stake, leading to superior returns at the expense of fewer managed investments.

These results, taken as a whole, provide powerful support for our equilibrium model, along the lines of Berk and Green (2004), that hedge funds face capacity constraints in their operations, and differentially allocate capital across their funds to maximize profits, depending on the mix of inside and outside capital. When funds rely on outside capital, managers are compensated primarily from managerial fees and leave little value to outside investors. Greater reliance on internal financing better aligns the incentives of managers and outside investors, leading them to leave substantial "slack" in fund size and operate strategies on at a smaller size, thereby receiving greater excess returns, even in a competitive market-but at the cost of outsider investor participation.

Our results contribute to the ongoing debates regarding the presence of managerial alpha and financial rents. Many observers are puzzled at the apparently outsize rents 
earned by financial intermediaries such as hedge funds, even in the wake of apparently strong competition and the role of fund inflows on diminishing returns. In turn, these managerial rents have driven top-end wealth and income inequality (see Kaplan and Rauh (2013)). We suggest that a possible reconciliation of these facts can be found in examining the option that fund managers have of not only earning management and performance fees, but also deploying their own capital in funds they manage. 


\section{REFERENCES}

Ackermann, Carl, Richard McEnally, and David Ravenscraft, 1999, The performance of hedge funds: Risk, return, and incentives, Journal of Finance 54, 833-874.

Agarwal, Vikas, Eser Arisov, and Narayan Naik, 2015, Volatility of aggregate volatility and hedge fund returns, Working Paper.

Agarwal, Vikas, Naveen Daniel, and Narayan Naik, 2009, Role of managerial incentives and discretion in hedge fund performance, Journal of Finance 64, 2221-2256.

Agarwal, Vikas, Stefan Ruenzi, and Florian Weigert, 2017, Tail risk in hedge funds: A unique view from portfolio holdings, Journal of Financial Economics 125, 610-636.

Berk, Jonathan, Jules van Binsbergen, and Binying Liu, 2017, Matching capital and labor, Journal of Finance, forthcoming.

Berk, Jonathan B., and Richard C. Green, 2004, Mutual fund flows and performance in rational markets, Journal of Political Economy 112, 1269-1295.

Berk, Jonathan B., and Jules H. van Binsbergen, 2017, Mutual funds in equilibrium, Working Paper.

Bollen, Nicolas PB, and Veronika K Pool, 2008, Conditional return smoothing in the hedge fund industry, Journal of Financial and Quantitative Analysis 43, 267-298.

Bollen, Nicolas PB, and Veronika K Pool, 2009, Do hedge fund managers misreport returns? evidence from the pooled distribution, Journal of Finance 64, 2257-2288.

Bris, Arturo, Huseyin Gulen, Padma Kadiyala, and P Raghavendra Rau, 2006, Good stewards, cheap talkers, or family men? the impact of mutual fund closures on fund managers, flows, fees, and performance, Review of Financial Studies 20, 953-982.

Brown, Stephen, William Goetzmann, Bing Liang, and Christopher Schwarz, 2008, Mandatory disclosure and operational risk: Evidence from hedge fund registration, Journal of Finance 63, 2785-2815.

Burasachi, Andrea, Robert Kosowski, and Worrawat Sritrakul, 2014, Incentives and endogenous risk taking: A structural view on hedge fund alphas, Journal of Finance 69, 2819-2870.

Carhart, Mark, 1997, On persistence in mutual fund performance, Journal of Finance 52, 57-82.

Chen, Joseph, Harrison Hong, Ming Huang, and Jeffrey Kubik, 2004, Does fund size erode mutual fund performance? the role of liquidity and organization, American Economic Review 94, 1276-1302.

Chen, Qi, Itay Goldstein, and Wei Jiang, 2008, Directors' ownership in the us mutual fund industry, Journal of Finance 63, 2629-2677. 
Chevalier, Judith, and Glenn Ellison, 1997, Risk taking by mutual funds as a response to incentives, Journal of Political Economy 105, 1167-1200.

Evans, Richard, 2010, Mutual fund incubation, Journal of Finance 4, 1581-1611.

Fama, Eugene, and Kenneth French, 1992, The cross-section of expected stock returns, Journal of Finance 47, 427-465.

Fama, Eugene, and James MacBeth, 1973, Risk, return, and equilibrium: Empirical tests, Journal of Political Economy 607-636.

Fung, William, and David Hsieh, 2004, Hedge fund benchmarks: A risk-based approach, Financial Analysts Journal 6o, 65-80.

Fung, William, David Hsieh, Narayan Naik, and Tarun Ramadorai, 2008, Hedge funds: Performance, risk, and capital formation, Journal of Finance 63, 1777-1803.

Getmansky, Mila, 2012, The life cycle of hedge funds: Fund flows, size, competition, and performance, The Quarterly Journal of Finance 2, 1250003.

Getmansky, Mila, Bing Liang, Christopher Schwarz, and Russ Wermers, 2015, Share restrictions and investor flows in the hedge fund industry, Working Paper.

Getmansky, Mila, Andrew Lo, and Igor Makarov, 2004, An econometric model of serial correlation and illiquidity in hedge fund returns, Journal of Financial Economics 74, 529609 .

Ibert, Markus, Ron Kaniel, Stijn Van Nieuwerburgh, and Roine Vestman, 2017, Are mutual fund managers paid for investment skill?, Review of Financial Studies, forthcoming.

Jorion, Philippe, and Christopher Schwarz, 2014, The strategic listing decisions of hedge funds, Journal of Financial and Quantitative Analysis 49, 773-796.

Kaplan, Steven, and Joshua Rauh, 2013, It's the market: The broad-based rise in the return to top talent, Journal of Economic Perspectives 27, 35-56.

Kruttli, Mathias, Phillip Monin, and Sumudu Watugala, 2019, Investor concentration, flows, and cash holdings: Evidence from hedge funds, Working Paper.

Massa, Massimo, 2003, How do family strategies affect fund performance? when performance-maximization is not the only game in town, Journal of Financial Economics $67,249-304$.

Ozik, Gideon, and Ronnie Sadka, 2015, Skin in the game versus skimming the game: Governance, share restrictions, and insider flows, Journal of Financial and Quantitative Analysis 50, 1293-1319.

Patton, Andrew, and Tarun Ramdorai, 2013, On the high-frequency dynamics of hedge fund risk exposures, Journal of Finance 68, 597-635.

Patton, Andrew J, Tarun Ramadorai, and Michael Streatfield, 2015, Change you can believe in? hedge fund data revisions, The Journal of Finance 70, 963-999. 
Petersen, Mitchell A, 2009, Estimating standard errors in finance panel data sets: Comparing approaches, Review of Financial Studies 22, 435-480.

Qiu, Judy, Leilei Tang, and Ingo Walter, 2016, Hedge fund incentives, management commitment and survivorship, Working Paper.

Ramadorai, Tarun, 2013, Capacity constraints, investor information, and hedge fund returns, Journal of Financial Economics 107, 401-416.

Shleifer, Andrei, and Robert Vishny, 1997, The limits of arbitrage, Journal of Finance 52, $35-55$.

Sialm, Clemens, and Mandy Tham, 2017, Spillover effects in mutual fund companies, Management Science, forthcoming.

Sirri, Erik R, and Peter Tufano, 1998, Costly search and mutual fund flows, Journal of Finance $53,1589-1622$.

Teo, Melvyn, 2009, Does size matter in the hedge fund industry?, Working paper, Singapore Management University .

Teo, Melvyn, 2011, The liquidity risk of liquid hedge funds, Journal of Financial Economics 24-44.

Yan, Xuemin, 2008, Liquidity, investment style, and the relation between fund size and fund performance, Journal of Financial and Quantitative Analysis 43, 741-767.

Yin, Chengdong, 2016, The optimal size of hedge funds: Conflict between investors and fund managers, Journal of Finance 71, 1857-1894. 


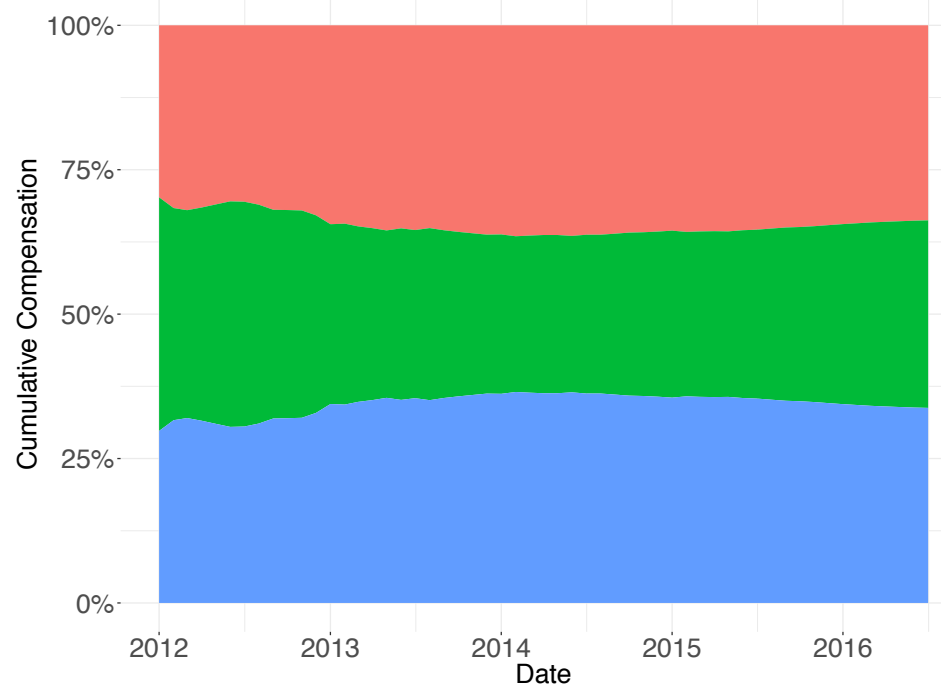

FIGURE I Decomposition of Earnings for Hedge Fund Managers

This figure distinguishes between three possible sources of hedge fund earnings-managerial fees (blue), performance fees (green), and excess returns on privately invested capital (red). The sample is restricted to funds for which all fee data are available, and the sample excludes eVestment (for which we do not have accurate assets under management data). To compute management fees, we multiply listed management fees for each fund against monthly assets under management invested by outside investors (assuming that insiders do not pay fees). Performance fees are computed assuming that all funds operate under a high-water mark which begins the first month for which we observe each fund's performance. Stated performance fees are multiplied by the total raw return (assuming no hurdle rate) on outsider fund investment. Insider returns are calculated based on each fund's excess return from a Fung-Hsieh Seven-Factor model multiplied by the quantity of inside investment in place within each fund. 


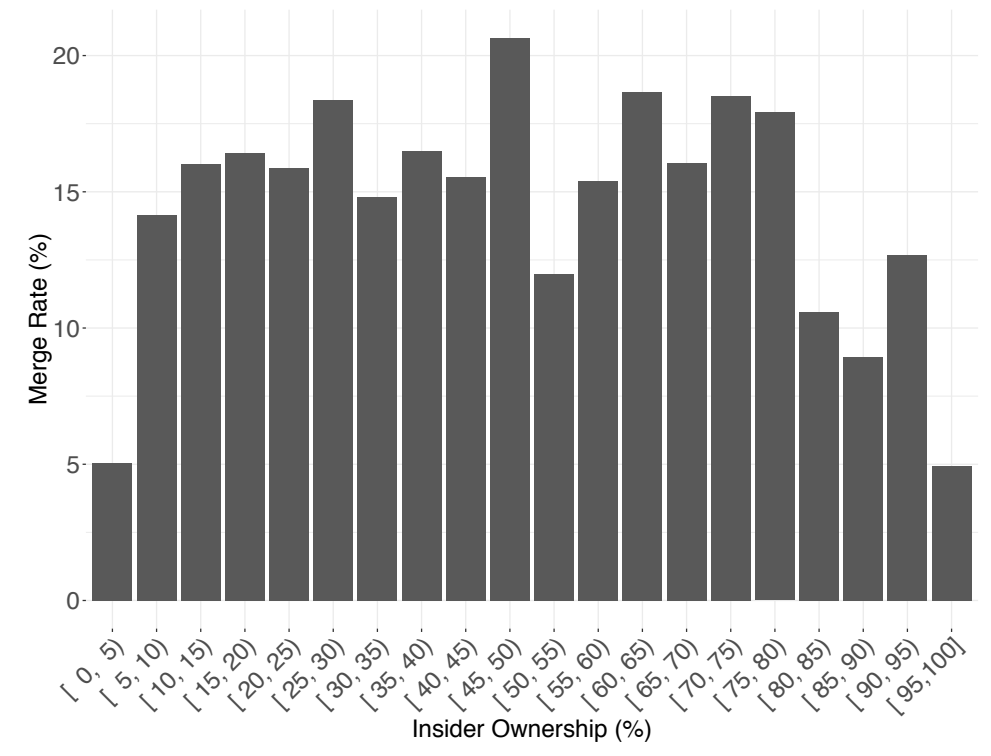

Panel A: Among ADV Hedge Funds, merge rate into Commercial Datasets

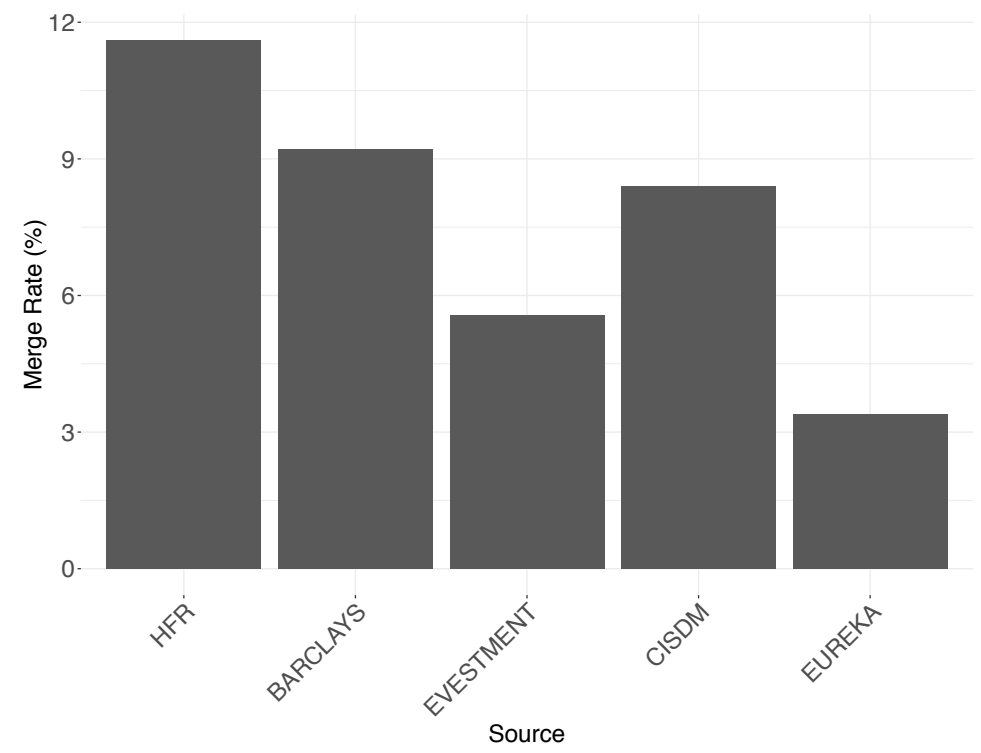

Panel B: Merge Rate by Commercial Data Provider

\section{FIGURE II Merge Details}

This figure plots the merge rate between observations in Form ADV and those in hedge fund commercial return datasets (outlined in the data section). All data are taken as of 2015. In Panel A, we report the fraction of observations in the ADV dataset for which we find a merged counterpart in the commercial return datasets, with the fraction reported for each 5-point interval of inside investment. In Panel B, we report the merge rate as a fraction of the total funds listed in each of the commercial hedge fund data providers. The order of the datasets reflects the sequential match process-we first search for matches in HFR, then BarclayHedge, then eVestment, then CISDM, then Eureka. For this reason, the match rate for each dataset reflects a conditional match rate, given that the fund did not merge in the previous dataset, and so our merge rates generally decrease as we move across providers. 


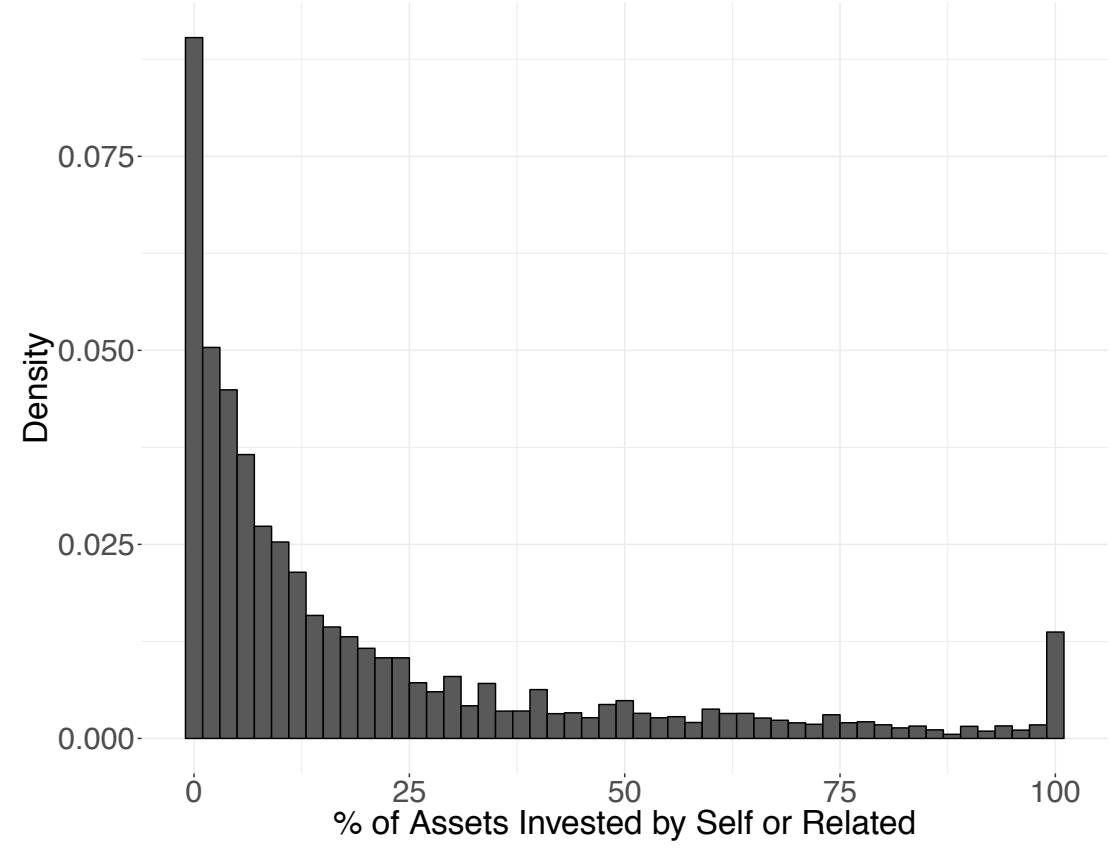

Panel A: Distribution of Insider Investment Across Funds, Percentage of Total Assets

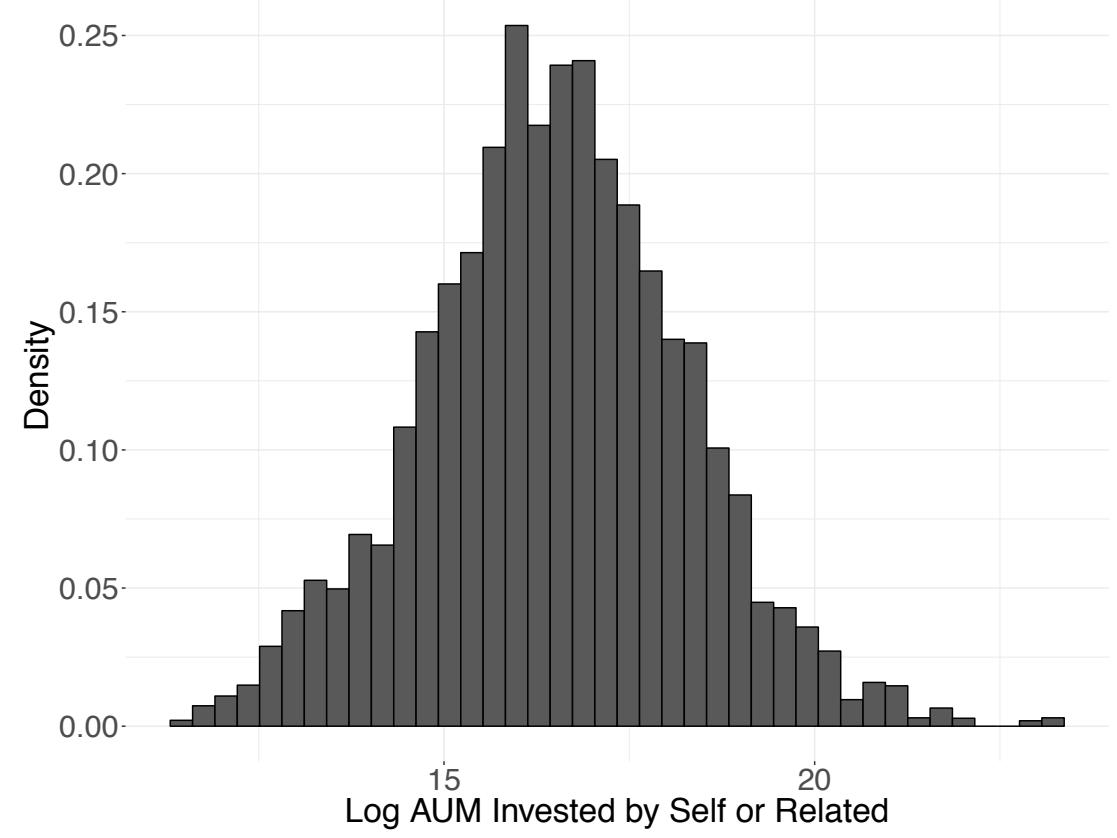

Panel B: Distribution of Insider Investment Across Funds, Gross Inside Investment

\section{FIGURE III Distribution of Insider Investment from Merged Sample}

This figure plots insider investment into hedge funds from the merged sample of hedge fund returns and ADV forms. Panel A is a histogram of insider investment, with units of percent of total investment. Insider investment displays a "dugebbell" distribution. Panel B is a histogram of $\log$ (Gross Asset Value) of insider investment across funds for the merged sample between ADV and the commercial hedge fund datasets. 


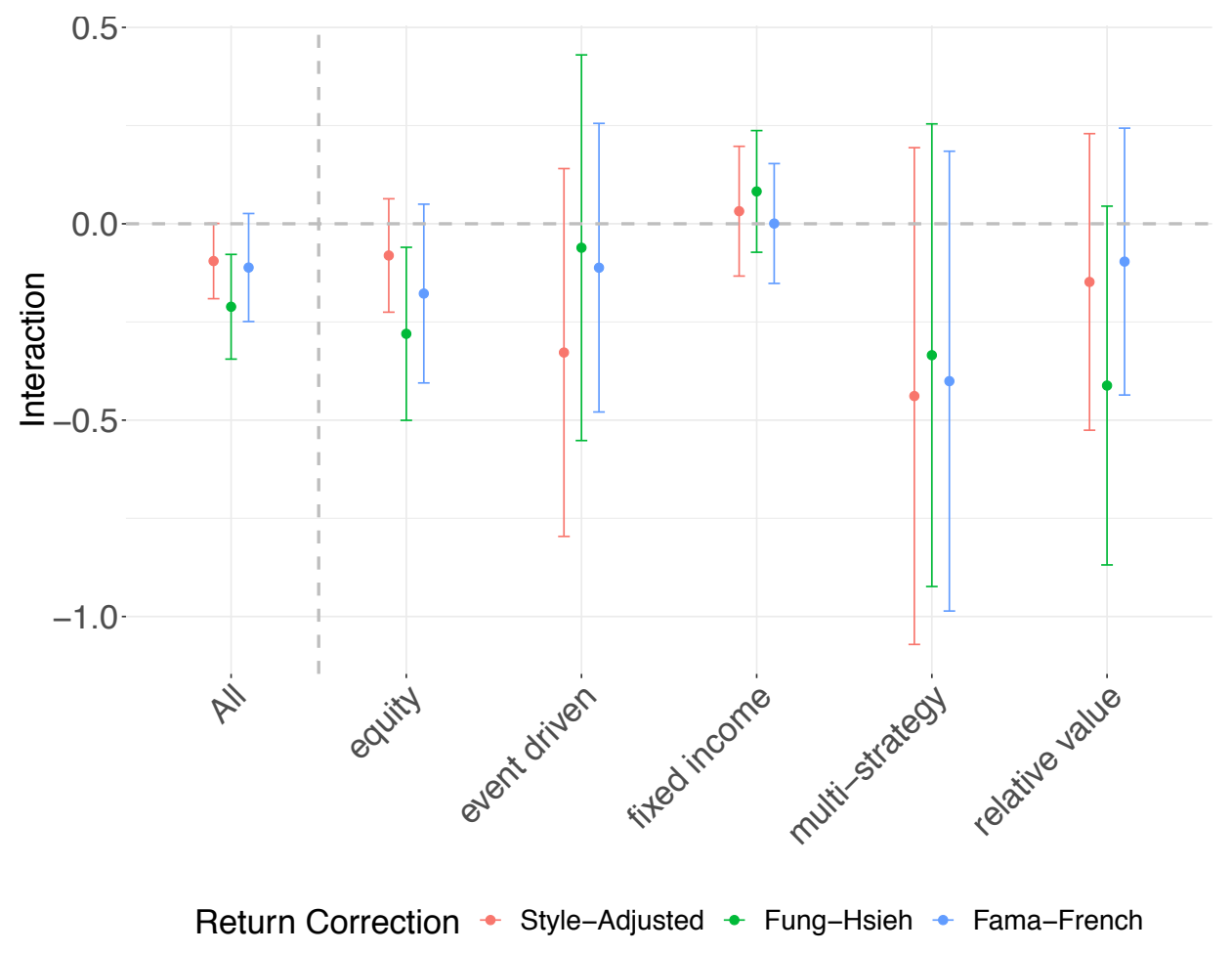

FIGURE IV Insider Investment Allocation by Fund Scale

This figure plots the coefficients from a regression estimating a decreasing returns to scale parameter interacted with an indicator for high investment funds. The specification, following Yin (2016), regresses measures of excess return against a number of covariates: Excess Return $n_{i, t}=$ $\beta \log \left(A U M_{i, t-1}\right) \times$ High Ownership $i_{i, t-1}+$ controls $+\varepsilon_{i, t}$. Measures of excess return include the return in excess of the style average (following Yin (2016)), as well as the Fama-French and Fung-Hsieh factor models. Controls include $\log \left(A U M_{t-1}\right), \log \left(\right.$ total firm $\left.A U M_{t-1}\right)$, percent AUM Flow $w_{t-1 \rightarrow t}$, performance fee, management fee, highwater mark, $\log$ (level of minimum investment), redemption period, fund age, whether the fund is open to new investment, and leverage. Further, we include fixed effects for the firm, year, and strategy, clustering at the fund level. All flow and return measures are winsorized at the $1 \%$ level. The key parameter plotted is $\beta$, which captures the extent to which high insider funds experience greater dilution of returns when more capital is deployed, consistent with returns to scale which are more decreasing. 


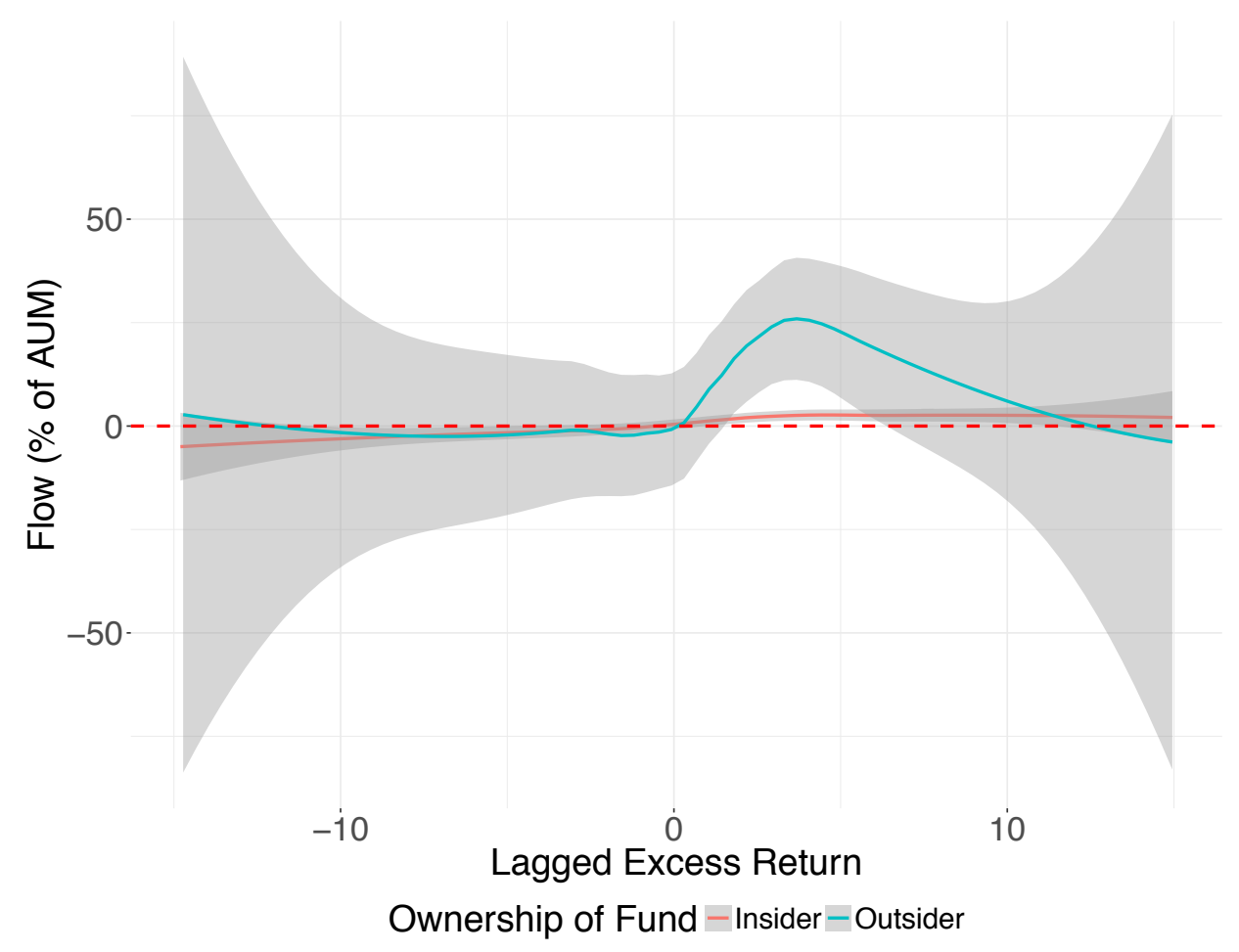

\section{FIGURE V Flow-Performance Relationship of Funds, Split by Insider Fund Status}

This figure plots the density of the relationship between lagged excess return and contemporaneous flow, measured quarterly. The flow measure is defined as $F l o w_{i t}=\frac{A U M_{i t}-\left(1+r_{i t}\right) \cdot A U M_{i, t-1}}{A U M_{i, t-1}}$. Excess returns are defined using the Fung-Hsieh Seven-Factor model. Funds are divided by the average level of inside investment into insider funds ( $>20.8 \%$ Inside Investment) and outsider funds. Grey bars correspond to $95 \%$ confidence intervals. Flows are winsorized at a $1 \%$ level. 


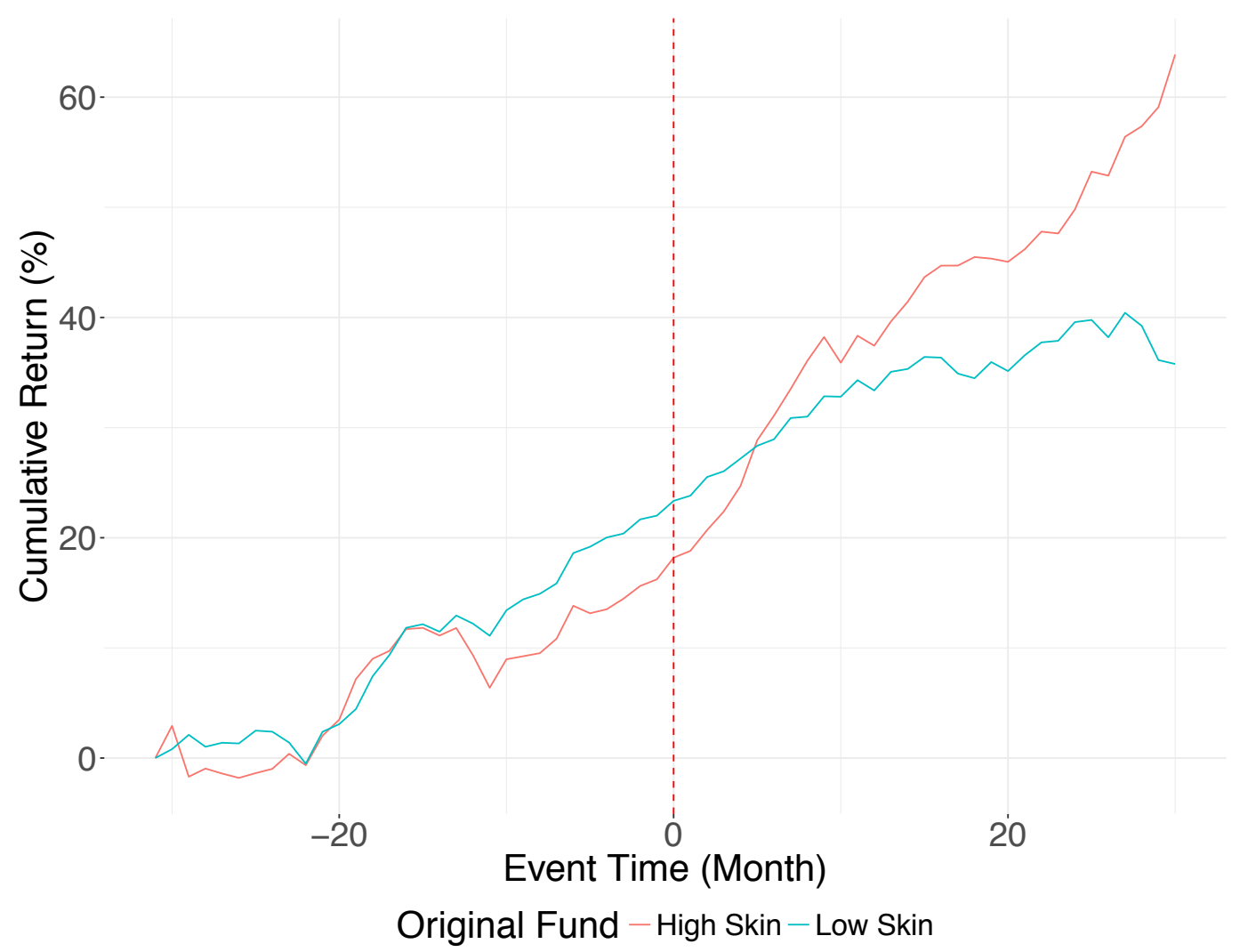

FIGURE VI Event Study, Transition From One Fund to Multiple Funds, Within a Firm

This figure plots the net cumulative returns of a firm which launches an additional fund after previously only having one. Event times correspond to months from the fund creation date. The lines plot the cumulative performance of the original fund, with the red line tracking a fund in which inside investment increases in the original fund after new fund creation (suggesting that the newly created fund is marketed to outside investors). The blue line tracks the performance of funds in which inside investment the original fund falls after new fund creation (suggesting that the original fund is marketed to outside investors). The red line's post-fund creation rise in returns indicates that fund performance improves when inside investment is strengthened in the fund. In a difference-in-difference regression, the interacted term of High Inside $\times$ Post has a coefficient of 0.969 and a standard error of 0.214 , which is significant at the $1 \%$ level. 


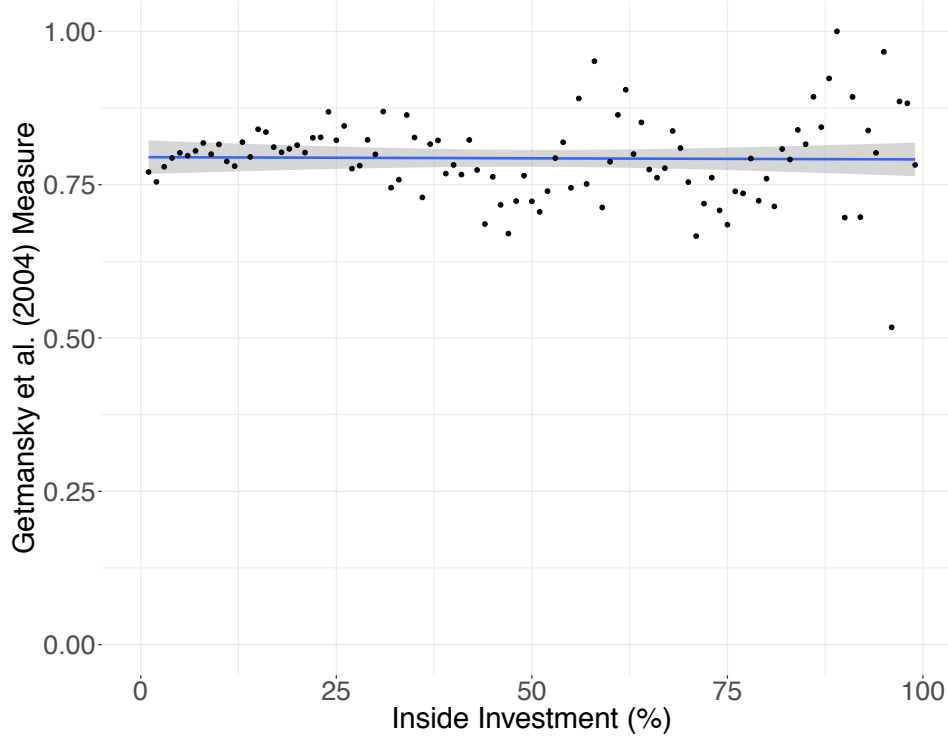

Panel A: Liquidity and Inside Investment

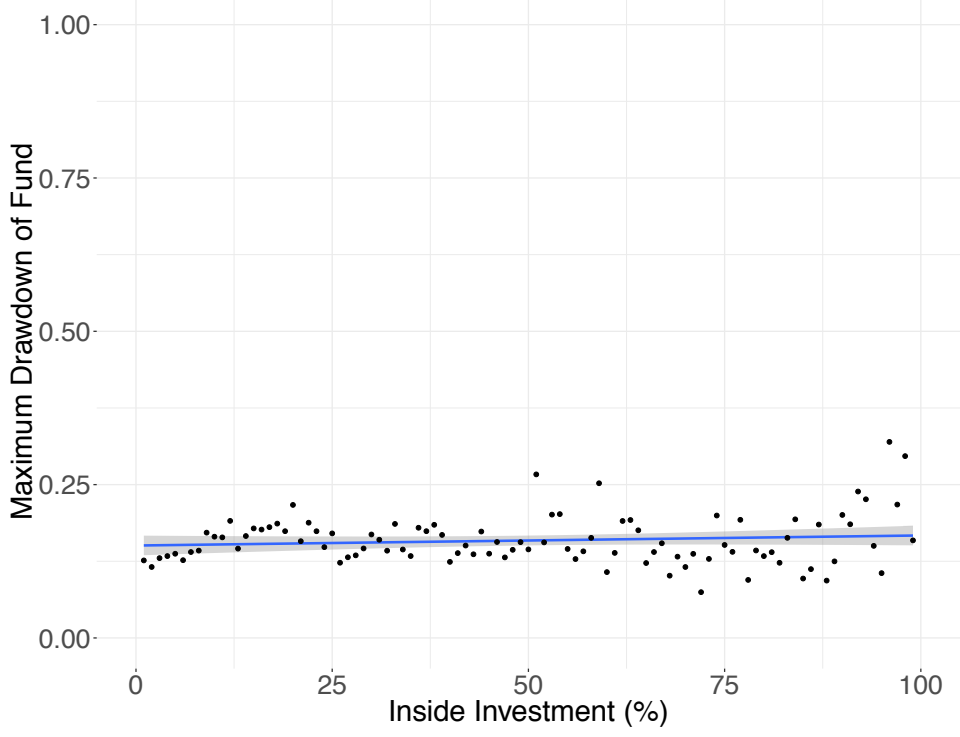

Panel B: Maximum Drawdown and Inside Investment

\section{FIGURE VII Alternative Risks and Inside Investment}

This figure explores the relationship between alternate possible risks and inside investment. In Panel A, we examine asset liquidity. To measure liquidity, we adopt the return smoothing measure from Getmansky, Lo, and Makarov (2004). For each percent of inside investment, we compute the average normalized measure of liquidity risk, as highlighted in that paper. Lower measures correspond to greater autocorrelation, indicative of less liquidity; higher numbers associate with less autocorrelation, associated with more liquidity (or a worse fit). In Panel B, we plot the distribution of maximum drawdowns (the greatest percentage loss in the fund's history, relative to the maximum attained asset value) across inside investment, so higher numbers indicate a greater average percentage loss. For each percent of inside investment, we plot the average max drawdown for funds in that bucket. 


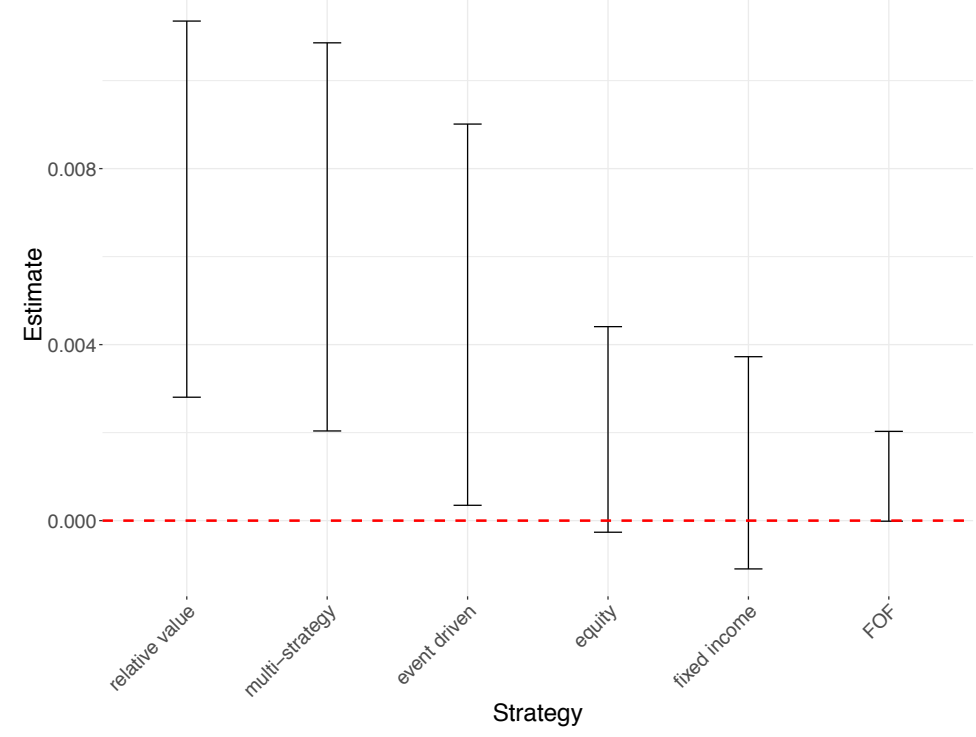

Panel A: Effects by Fund Type

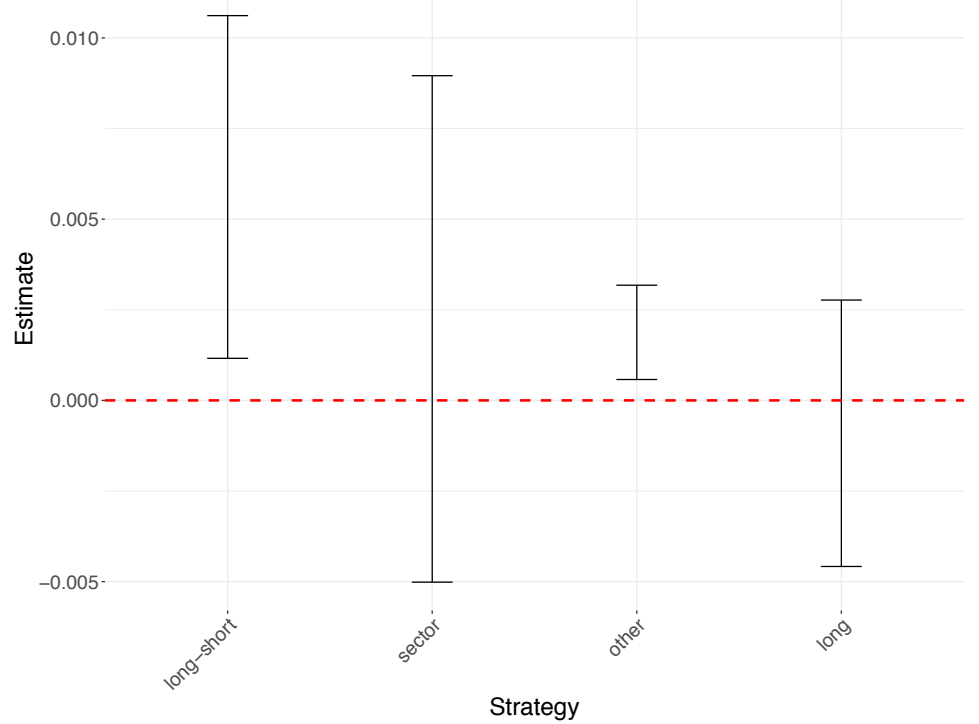

Panel B: Effects by Fund Type among Equity Funds

\section{FIGURE VIII Inside Investment Return Relationship by Fund Type}

This figure presents a robustness analysis of the specification in column 1 of Panel A of Table VIII, which is a panel regression of inside investment against factor-corrected returns. This figure plots the coefficient on inside investment, corresponding to the predictive value of that variable on excess returns, run in a separate regression for each fund category. Funds are categorized based on descriptions found in commercial hedge fund datasets, as listed in the Data section. The error bars indicate a $95 \%$ confidence interval for the estimated coefficients. 


\section{TABLE I Summary Statistics: ADV Data}

This summary table describes data on investment advisors taken from Form ADV in 2016. Data is only taken from funds which are registered as hedge funds; firms must have at least one hedge fund and a minimum level of assets of \$20 million. Panel A describes firm level information at the level of the management company. Panel B describes information available at the level of individual funds. Note that some assets may be double-counted due to the inclusion of fund of funds. Inside Investment corresponds to ownership by management or related parties, the key variable explored in this paper.

Panel A: Firm Level Variables

\begin{tabular}{lllll}
\hline Names & Total & Median & Mean & Std.Dev \\
\hline Custodial AUM $(\$ m)$ & $8,525,754.0$ & 775.5 & $6,458.9$ & $28,332.9$ \\
Regulatory AUM $(\$ m)$ & $18,084,715$ & $1,166.7$ & $13,700.5$ & $72,114.3$ \\
Discretionary AUM $(\$ m)$ & $17,518,589$ & $1,030.8$ & $13,271.7$ & $71,040.1$ \\
Non-Discretionary AUM $(\$ m)$ & 566,126 & 0 & 428.9 & $2,585.1$ \\
Number of Employees & 139,264 & 13 & 57.2 & 199.0 \\
$\quad$ - Support Staff & 81,033 & 5 & 33.3 & 132.9 \\
$\quad$ - Advisors & 58,231 & 7 & 23.9 & 75.6 \\
Number of Firms & 2,433 & & & \\
\hline
\end{tabular}

Panel B: Fund Level Variables

\begin{tabular}{lllll}
\hline Names & Total & Median & Mean & Std.Dev \\
\hline Number of Hedge Funds & 9,763 & & & \\
Gross Asset Value (\$m) & $6,177,174.0$ & 127.8 & 632.7 & $3,060.7$ \\
Gross Assets, Inside Investment (\$m) & 772,663 & 3.8 & 79.1 & 553.2 \\
Gross Assets, Fund of Funds (\$m) & $1,160,354.0$ & 0 & 118.9 & 873 \\
Gross Assets, Non-US Investors (\$m) & $2,492,344.0$ & 4.7 & 255.3 & $1,698.6$ \\
Number of Owners & & 19 & 66.8 & 544.3 \\
Minimum Investment (\$m) & & 1 & 7.5 & 70.3 \\
Inside Investment (\%) & & 3 & 16.7 & 28.6 \\
Investment by Fund of Funds (\%) & & 0 & 15.9 & 29.5 \\
Non-US Investors (\%) & 2,322 & & 30.7 & 39.0 \\
Number of Fund of Funds & & & \\
\hline
\end{tabular}




\section{TABLE II Summary Statistics: Merged Data}

This summary table describes data on the primary dataset based on a merged dataset of Form ADV and commercial hedge fund data providers (Eureka, HFR, BarclaysHedge, eVestment, and CISDM). Data is taken as of 2016. Data is only taken from funds which are registered as hedge funds; firms must have at least one hedge fund and a minimum level of assets of $\$ 20$ million. Panel A describes firm level information at the level of the management company. Panel B describes information available at the level of individual funds. Note that some assets may be double-counted due to the inclusion of fund of funds. Panel B reports additional variables not included in Table 1 . Inside Investment corresponds to ownership by management or related parties, the key variable explored in this paper.

\section{Panel A: Firm Level Variables}

\begin{tabular}{lllll}
\hline Names & Total & Median & Mean & Std.Dev \\
\hline Custodial AUM & $1,195,040.0$ & 591 & $5,218.5$ & $16,444.6$ \\
Regulatory AUM & $1,759,749.0$ & 1,022 & $7,684.5$ & 27,716 \\
Discretionary AUM & $1,750,849$ & 952.9 & $7,645.6$ & $27,633.2$ \\
Non-Discretionary AUM & $8,899.7$ & 0 & 38.9 & 195.1 \\
$\quad$ - Number of Employees & 16,665 & 12 & 38.8 & 100.4 \\
$\quad$ - Number of Support Staff & 9,941 & 5 & 23.1 & 72.4 \\
Advisors & 6,724 & 6 & 15.6 & 29.9 \\
Number of Firms & 504 & & & \\
\hline
\end{tabular}

Panel B: Fund Level Variables

\begin{tabular}{lllll}
\hline Names & Total & Median & Mean & Std.Dev \\
\hline Number of Hedge Funds & 720 & & & \\
Gross Asset Value (\$m) & $497,625.5$ & 88.3 & 278.3 & 708.9 \\
$\quad$ - Equity & $219,868.9$ & & & \\
$\quad$ - Relative Value & $122,522.7$ & & & \\
$\quad$ - Fund of Funds & $53,330.4$ & & & \\
$\quad$ - Multi-Strategy & $55,526.5$ & & & \\
$\quad$ - Fixed Income & $29,912.7$ & & & \\
$\quad$ - CTA & $26,240.1$ & & & \\
$\quad$ - Event Driven & $22,403.2$ & & & \\
$\quad$ - Other & $20,527.9$ & & & \\
$\quad$ - Options & 623.5 & & & \\
Gross Assets, Inside Investment (\$m) & $61,380.4$ & 11.9 & 41.5 & 108.8 \\
Gross Assets, Fund of Funds (\$m) & $73,352.2$ & 0 & 45.8 & 200.8 \\
Gross Assets, Non-US Investors (\$m) & $176,673.4$ & 0.2 & 112.5 & 400.9 \\
Number of Owners & & 39 & 162.3 & 865.0 \\
Minimum Investment (\$m) & & 1 & 1.1 & 3.3 \\
Inside Investment (\%) & & 10 & 22.8 & 27.1 \\
Investment by Fund of Funds (\%) & & 0 & 9.0 & 16.7 \\
Non-US Investors (\%) & & 1 & 24.6 & 36.2 \\
Management Fee & & 1.5 & 1.5 & 0.5 \\
Performance Fee & & 20 & 18.2 & 5.4 \\
Leverage Ratio & & 1.1 & 1.5 & 0.9 \\
\hline
\end{tabular}




\section{TABLE III Related Party Information}

This table illustrates the identity of related parties, as listed in form ADV in 2016. The rows need not sum to one: firms select as many options as needed to identify all related parties.

\begin{tabular}{lcc}
\hline Statistic & Mean & SD \\
\hline Sponsor of GP & 0.741 & 0.438 \\
Other Investment Advisor & 0.501 & 0.500 \\
Commodity Pool & 0.401 & 0.490 \\
Broker/Dealer & 0.160 & 0.367 \\
Insurance & 0.065 & 0.246 \\
Sponsor of LP & 0.046 & 0.210 \\
Bank or Thrift & 0.045 & 0.207 \\
Trust & 0.042 & 0.201 \\
Pension & 0.027 & 0.161 \\
Accountant & 0.025 & 0.156 \\
Real Estate & 0.024 & 0.153 \\
Lawyer & 0.019 & 0.138 \\
Municipal Advisor & 0.013 & 0.113 \\
Futures Merchant & 0.009 & 0.094 \\
Swap Dealer & 0.007 & 0.081 \\
Swap Participant & 0.001 & 0.026 \\
\hline Share Supervised Persons & $74 \%$ & \\
Share Office & $59 \%$ & \\
\hline
\end{tabular}




\section{TABLE IV Summary Statistics of Dependent Variables}

This table presents the summary statistics of key dependent variable used throughout the paper. Each panel summarizes the 10th, 25th, 5oth, and 9oth percentile, as well as the mean and standard deviation. Years include 2011 through 2016, inclusive. Panel A summarizes the excess return imputed by a Fama-French and Carhart model. Panel B summarizes the excess return imputed by the a Fung-Hsieh model. Panel $\mathrm{C}$ summarizes the percent asset flow, computed quarterly, and winsorized at the $1 \%$ level. Panel D summarizes the percent of inside investment at the fund level.

Panel A: Alpha from Fama-French and Carhart Model

\begin{tabular}{cccccccc}
\hline Year & $10 \%$ & $25 \%$ & $50 \%$ & $75 \%$ & $90 \%$ & Mean & St.Dev \\
\hline 2011 & -3.73 & -1.68 & -0.16 & 1.00 & 2.49 & -0.46 & 3.25 \\
2012 & -2.28 & -0.79 & 0.31 & 1.31 & 2.68 & 0.24 & 2.53 \\
2013 & -2.28 & -0.85 & 0.18 & 1.13 & 2.49 & 0.14 & 2.56 \\
2014 & -2.55 & -0.96 & 0.14 & 1.17 & 2.71 & 0.14 & 3.25 \\
2015 & -2.77 & -1.09 & 0.13 & 1.25 & 2.90 & 0.16 & 3.26 \\
2016 & -3.36 & -1.58 & -0.02 & 1.15 & 2.77 & -0.26 & 3.13 \\
\hline
\end{tabular}

Panel B: Alpha from Fung-Hsieh Model

\begin{tabular}{cccccccc}
\hline Year & $10 \%$ & $25 \%$ & $50 \%$ & $75 \%$ & $90 \%$ & Mean & St.Dev \\
\hline 2011 & -3.49 & -1.17 & 0.27 & 1.69 & 3.94 & 0.18 & 3.72 \\
2012 & -2.59 & -0.84 & 0.37 & 1.54 & 3.18 & 0.32 & 2.85 \\
2013 & -1.51 & -0.20 & 0.84 & 2.18 & 3.87 & 1.04 & 2.73 \\
2014 & -2.81 & -0.97 & 0.40 & 1.82 & 3.73 & 0.45 & 3.49 \\
2015 & -3.48 & -1.24 & 0.28 & 1.69 & 3.76 & 0.23 & 3.57 \\
2016 & -3.79 & -1.25 & 0.31 & 1.73 & 3.69 & 0.07 & 3.54 \\
\hline
\end{tabular}

Panel C: Percent Flow, Quarterly

\begin{tabular}{cccccccc}
\hline Year & $10 \%$ & $25 \%$ & $50 \%$ & $75 \%$ & $90 \%$ & Mean & St.Dev \\
\hline 2011 & -9.66 & -4.11 & -0.44 & 1.29 & 6.49 & -1.13 & 10.83 \\
2012 & -10.55 & -3.45 & -0.07 & 2.96 & 11.92 & 1.04 & 14.78 \\
2013 & -9.26 & -2.93 & 0.24 & 4.09 & 17.89 & 2.86 & 17.21 \\
2014 & -7.66 & -2.56 & 0.02 & 3.31 & 12.38 & 1.59 & 14.53 \\
2015 & -8.49 & -3.12 & -0.51 & 1.49 & 9.62 & 0.42 & 12.20 \\
2016 & -10.08 & -3.82 & -0.57 & 1.59 & 8.58 & -0.32 & 12.42 \\
\hline
\end{tabular}

Panel D: Inside Investment, Percentage

\begin{tabular}{cccccccc}
\hline Year & $10 \%$ & $25 \%$ & $50 \%$ & $75 \%$ & $90 \%$ & Mean & St.Dev \\
\hline 2011 & 2 & 4 & 9 & 22 & 46 & 17.35 & 20.87 \\
2012 & 2 & 4 & 10 & 23 & 50 & 17.89 & 21.04 \\
2013 & 2 & 4 & 10 & 25 & 54 & 19.11 & 21.59 \\
2014 & 2 & 5 & 11 & 26 & 58 & 20.15 & 22.48 \\
2015 & 2 & 5 & 11 & 25 & 58 & 20.19 & 22.72 \\
2016 & 2 & 5 & 11 & 435 & 59 & 20.23 & 22.74 \\
\hline
\end{tabular}




\section{TABLE V Inside Investment and Fund Size}

This table shows the panel regression between size and inside investment. Panel A conducts analysis on the matched sample connecting Form ADV with commercial hedge fund datasets (where the key dependent variable is assets under management, taken from the commercial hedge fund datasets, reported as the log of AUM or in millions). Panel B performs analysis on the complete ADV dataset, using Gross Asset Value as the dependent variable. All specifications regress the fraction of the fund which consists on insider investment against a measure of size, measured yearly. Across all specifications, columns 1 and 3 perform this regression with no additional controls; columns 2 and 4 add firm and year fixed effects. Standard errors are in parenthesis.

Panel A: Results on Matched Dataset

\begin{tabular}{lccccc}
\hline & \multicolumn{2}{c}{ AUM (in \$m) } & & \multicolumn{2}{c}{$\log (\mathrm{AUM})$} \\
\cline { 2 - 3 } \cline { 5 - 6 } & $(1)$ & $(2)$ & & $(3)$ & $(4)$ \\
\hline Inside Investment (Percent) & $-3.82^{* * *}$ & $-7.86^{* * *}$ & & $-0.01^{* * *}$ & $-0.02^{* * *}$ \\
& $(0.24)$ & $(1.20)$ & & $(0.001)$ & $(0.003)$ \\
& & & & \\
\hline Year FE & No & Yes & & No & Yes \\
Firm FE & No & Yes & & No & Yes \\
Fund Controls & No & Yes & & No & Yes \\
Dataset & Matched & Matched & & Matched & Matched \\
Observations & 2,633 & 2,633 & & 2,633 & 2,633 \\
$\mathrm{R}^{2}$ & 0.01 & 0.88 & & 0.02 & 0.86 \\
\hline
\end{tabular}

Panel B: Results on ADV Dataset

\begin{tabular}{|c|c|c|c|c|}
\hline & \multicolumn{2}{|c|}{ Gross Asset Value (in $\$ \mathrm{~m}$ ) } & \multicolumn{2}{|c|}{ Log(Gross Asset Value) } \\
\hline & $(1)$ & $(2)$ & (3) & (4) \\
\hline Inside Investment (Percent) & $\begin{array}{c}-6.34^{* * *} \\
(0.89)\end{array}$ & $\begin{array}{c}-10.14^{* * *} \\
(1.12)\end{array}$ & $\begin{array}{c}-0.01^{* * *} \\
(0.001)\end{array}$ & $\begin{array}{c}-0.02^{* * *} \\
(0.001)\end{array}$ \\
\hline Year FE & No & Yes & No & Yes \\
\hline Firm FE & No & Yes & No & Yes \\
\hline Fund Controls & No & Yes & No & Yes \\
\hline Dataset & ADV & ADV & ADV & ADV \\
\hline Observations & 35,960 & 35,960 & 35,960 & 35,960 \\
\hline $\mathrm{R}^{2}$ & 0.002 & 0.57 & 0.03 & 0.57 \\
\hline
\end{tabular}




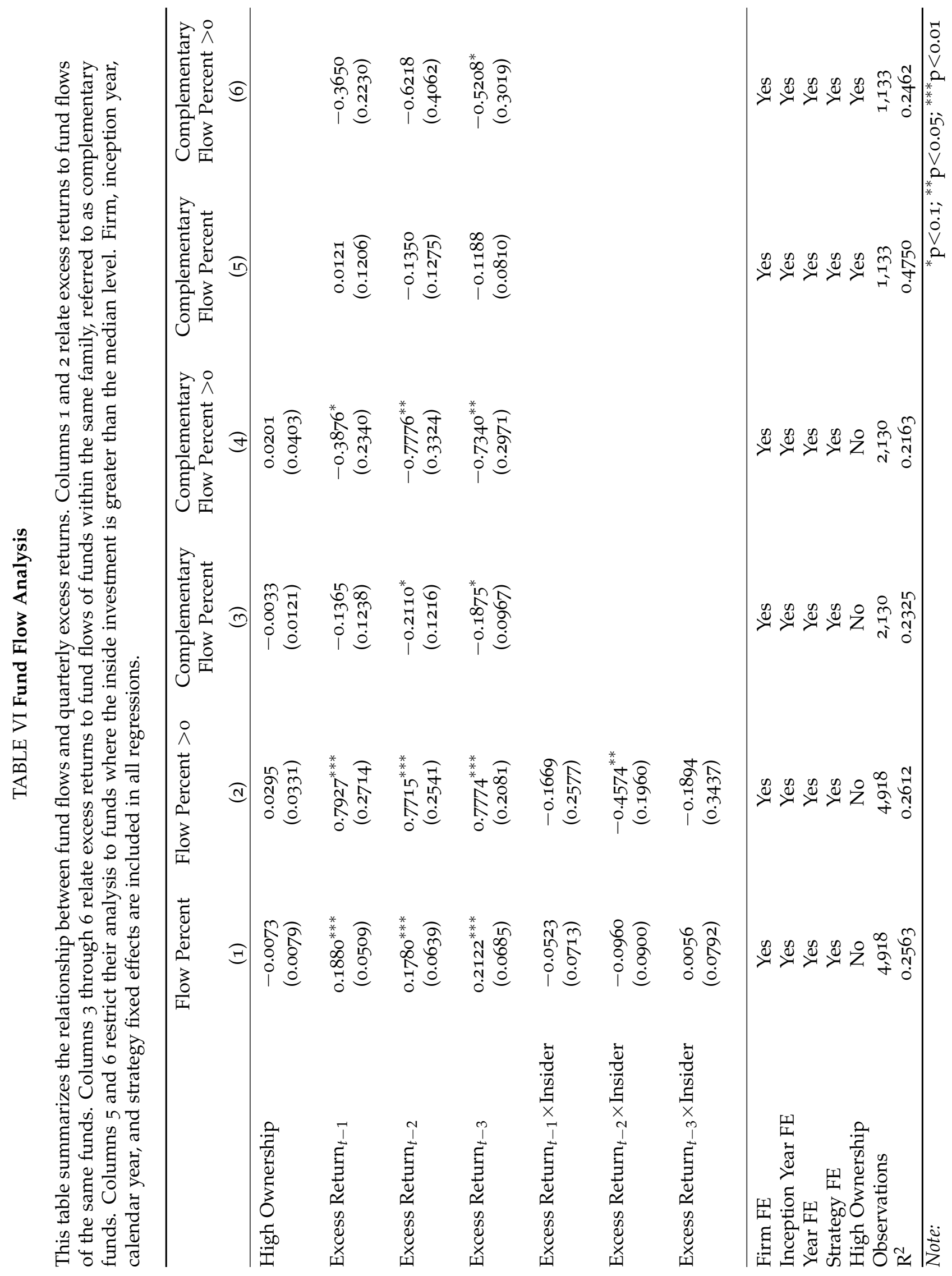




\section{TABLE VII Open for New Investments}

This table shows the panel regressions between fund and whether they are open for new investments. The analysis is based on the HFR, Eurekahedge, and BarclayHedge datasets. Columns 1 and 2 relate percent of inside investment to the openness of a fund. Columns 3 and 4 relate the openness of the fund to monthly excess returns, as measured by the Fung-Hsieh Seven-Factors model. Columns 5 and 6 similarly show results with and without controls for the Fama-French and Carhart model.

\begin{tabular}{|c|c|c|c|c|c|c|}
\hline & \multicolumn{2}{|c|}{ Open for Investors } & \multicolumn{2}{|c|}{ Excess Returns (FH) } & \multicolumn{2}{|c|}{ Excess Returns (FFC) } \\
\hline & (1) & $(2)$ & (3) & (4) & (5) & (6) \\
\hline Inside Investment $(\%)$ & $\begin{array}{c}-0.0013^{* * *} \\
(0.0003)\end{array}$ & $\begin{array}{c}-0.0021^{* * *} \\
(0.0003)\end{array}$ & & & & \\
\hline Open for Investors & & & $\begin{array}{c}-0.2291^{* *} \\
(0.0971)\end{array}$ & $\begin{array}{c}-0.2186^{* * *} \\
(0.0746)\end{array}$ & $\begin{array}{c}-0.4463^{* * *} \\
(0.0660)\end{array}$ & $\begin{array}{c}-0.3141^{* * *} \\
(0.0706)\end{array}$ \\
\hline Fixed Effects & No & Yes & No & Yes & No & Yes \\
\hline Log(Fund Size) & No & Yes & No & Yes & No & Yes \\
\hline Sample: & Yearly & Yearly & Monthly & Monthly & Monthly & Monthly \\
\hline Observations & 1,977 & 1,977 & 12,065 & 12,065 & 12,065 & 12,065 \\
\hline $\mathrm{R}^{2}$ & 0.0069 & 0.1385 & 0.0007 & 0.0168 & 0.0034 & 0.0130 \\
\hline
\end{tabular}




\section{TABLE VIII Relationship between Inside Investment and Excess Return}

This table shows the panel regression between the excess monthly return of an investment advisor and insider investment. Panel A measures inside investment as a percentage of fund assets, while Panel B uses the log of gross inside investment. The first three columns in both panels regress against the Fung-Hsieh Seven Factor measure of excess return, while the last three columns regress against the Fama-French and Carhart Four-Factor model, as outlined in equations 4 and 5 in the text. A size control is always included. Specifications (1) and (4) include only size and three lags of excess return. Specifications (2) and (5) add Firm fixed effects, month fixed effects, and fund level controls (age of fund inception and strategy type). Specifications (3) and (6) include size, three lags of excess return, and a fund fixed-effect. Standard errors are clustered monthly.

\section{Panel A Baseline Specification}

\begin{tabular}{|c|c|c|c|c|c|c|}
\hline & \multicolumn{3}{|c|}{ FH Excess Returns } & \multicolumn{3}{|c|}{ FFC Excess Returns } \\
\hline & $(1)$ & $(2)$ & (3) & (4) & (5) & $(6)$ \\
\hline Inside Investment (Percent) & $\begin{array}{l}0.0025^{* *} \\
(0.0010)\end{array}$ & $\begin{array}{c}0.0061^{* * *} \\
(0.0013)\end{array}$ & $\begin{array}{c}0.0066^{* * *} \\
(0.0022)\end{array}$ & $\begin{array}{c}0.0021^{* *} \\
(0.0009)\end{array}$ & $\begin{array}{c}0.0045^{* * *} \\
(0.0013)\end{array}$ & $\begin{array}{c}0.0054^{* *} \\
(0.0021)\end{array}$ \\
\hline $\operatorname{Return}_{i, t-1}$ & $\begin{array}{c}0.0066 \\
(0.0384)\end{array}$ & $\begin{array}{c}0.0087 \\
(0.0271)\end{array}$ & $\begin{array}{c}0.0022 \\
(0.0267)\end{array}$ & $\begin{array}{c}0.1027^{* * *} \\
(0.0206)\end{array}$ & $\begin{array}{c}0.0638^{* * *} \\
(0.0221)\end{array}$ & $\begin{array}{c}0.0577^{* *} \\
(0.0225)\end{array}$ \\
\hline $\operatorname{Return}_{i, t-2}$ & $\begin{array}{c}-0.0014 \\
(0.0331)\end{array}$ & $\begin{array}{c}-0.0140 \\
(0.0235)\end{array}$ & $\begin{array}{c}-0.0204 \\
(0.0228)\end{array}$ & $\begin{array}{c}0.0334 \\
(0.0238)\end{array}$ & $\begin{array}{c}0.0159 \\
(0.0227)\end{array}$ & $\begin{array}{c}0.0097 \\
(0.0225)\end{array}$ \\
\hline $\operatorname{Return}_{i, t-3}$ & $\begin{array}{c}0.0341 \\
(0.0369)\end{array}$ & $\begin{array}{l}-0.0126 \\
(0.0272)\end{array}$ & $\begin{array}{c}-0.0185 \\
(0.0271)\end{array}$ & $\begin{array}{c}0.0138 \\
(0.0202)\end{array}$ & $\begin{array}{l}-0.0132 \\
(0.0193)\end{array}$ & $\begin{array}{l}-0.0188 \\
(0.0194)\end{array}$ \\
\hline Month Fixed Effects & No & Yes & Yes & No & Yes & Yes \\
\hline Fund Level Controls & No & Yes & No & No & Yes & No \\
\hline Adviser Fixed Effects & No & Firm & Fund & No & Firm & Fund \\
\hline Observations & 37,958 & 37,958 & 37,958 & 37,958 & 37,958 & 37,958 \\
\hline $\mathrm{R}^{2}$ & 0.0020 & 0.1875 & 0.1941 & 0.0212 & 0.0843 & 0.0925 \\
\hline
\end{tabular}

Panel B: Gross Inside Investment

\begin{tabular}{|c|c|c|c|c|c|c|}
\hline & \multicolumn{3}{|c|}{ FH Excess Returns } & \multicolumn{3}{|c|}{ FFC Excess Returns } \\
\hline & $(1)$ & $(2)$ & (3) & (4) & $(5)$ & $(6)$ \\
\hline Inside Investment (Gross) & $\begin{array}{l}0.0406^{* *} \\
(0.0195)\end{array}$ & $\begin{array}{c}0.1010^{* * *} \\
(0.0227)\end{array}$ & $\begin{array}{c}0.1288^{* * *} \\
(0.0366)\end{array}$ & $\begin{array}{l}0.0246^{*} \\
(0.0144)\end{array}$ & $\begin{array}{c}0.0811^{* * *} \\
(0.0228)\end{array}$ & $\begin{array}{c}0.1165^{* * *} \\
(0.0434)\end{array}$ \\
\hline $\operatorname{Return}_{i, t-1}$ & $\begin{array}{c}0.0067 \\
(0.0384)\end{array}$ & $\begin{array}{c}0.0088 \\
(0.0271)\end{array}$ & $\begin{array}{c}0.0022 \\
(0.0275)\end{array}$ & $\begin{array}{c}0.1028^{* * *} \\
(0.0206)\end{array}$ & $\begin{array}{c}0.0639^{* * *} \\
(0.0221)\end{array}$ & $\begin{array}{c}0.0576^{* *} \\
(0.0225)\end{array}$ \\
\hline $\operatorname{Return}_{i, t-2}$ & $\begin{array}{l}-0.0013 \\
(0.0331)\end{array}$ & $\begin{array}{l}-0.0139 \\
(0.0235)\end{array}$ & $\begin{array}{l}-0.0204 \\
(0.0235)\end{array}$ & $\begin{array}{c}0.0335 \\
(0.0238)\end{array}$ & $\begin{array}{c}0.0159 \\
(0.0227)\end{array}$ & $\begin{array}{c}0.0096 \\
(0.0225)\end{array}$ \\
\hline $\operatorname{Return}_{i, t-3}$ & $\begin{array}{c}0.0342 \\
(0.0369)\end{array}$ & $\begin{array}{l}-0.0126 \\
(0.0272)\end{array}$ & $\begin{array}{c}-0.0186 \\
(0.0272)\end{array}$ & $\begin{array}{c}0.0139 \\
(0.0202)\end{array}$ & $\begin{array}{l}-0.0131 \\
(0.0193)\end{array}$ & $\begin{array}{l}-0.0189 \\
(0.0194)\end{array}$ \\
\hline Month Fixed Effects & No & Yes & Yes & No & Yes & Yes \\
\hline Fund Level Controls & No & Yes & No & No & Yes & No \\
\hline Adviser Fixed Effects & No & Firm & Fund & No & Firm & Fund \\
\hline Observations & 37,958 & 37,958 & 37,958 & 37,958 & 37,958 & 37,958 \\
\hline $\mathrm{R}^{2}$ & 0.0019 & 0.1874 & 0.1941 & 0.0211 & 0.0842 & 0.0925 \\
\hline
\end{tabular}




\section{TABLE IX Fund Flows and Performance}

This table shows the panel regression between size and flows by insiders and outsiders. "Insider Flow" corresponds to changes in capital provided by insiders and related parties, while "Outsider Flow" captures changes in capital provision by all other investors. Changes in both types of flow are measured annually with the release of new ADV forms. Column 2 adds year fixed effects, and column 3 adds firm fixed effects. Standard errors are clustered at the year level.

\begin{tabular}{|c|c|c|c|}
\hline & (1) & (2) & (3) \\
\hline Insider Flow (\%) & $\begin{array}{c}-0.00034 \\
(0.00023)\end{array}$ & $\begin{array}{c}-0.00025 \\
(0.00023)\end{array}$ & $\begin{array}{c}-0.00029 \\
(0.00039)\end{array}$ \\
\hline Outsider Flow (\%) & $\begin{array}{c}0.00002 \\
(0.00002)\end{array}$ & $\begin{array}{c}0.00003 \\
(0.00002)\end{array}$ & $\begin{array}{l}0.00003^{*} \\
(0.00002)\end{array}$ \\
\hline Size & Yes & Yes & Yes \\
\hline Year FE & No & Yes & Yes \\
\hline Firm FE & No & No & Yes \\
\hline Observations & 228 & 228 & 228 \\
\hline $\mathrm{R}^{2}$ & 0.00372 & 0.05192 & 0.11300 \\
\hline
\end{tabular}

